\title{
ADMINISTRAÇÃO DE POLÍTICAS EMERGENCIAIS DE SAÚDE. O CASO \\ ARGENTINA E BRASIL E A PANDEMIA DA GRIPE SUÍNA (H1N1)
}

EMERGENCY MANAGEMENT POLICIES OF HEALTH. THE CASE OF

ARGENTINA AND BRAZIL AND SWINE FLU PANDEMIC (H1N1)

\section{Istvan Karoly Kasznar}

\section{RESUMO}

A gripe suína H1N1 é nível seis de gravidade e representa uma pandemia no mundo atual. Ao apresentar características mutagênicas, seu combate torna-se complexo e o esclarecimento público mediante adequadas medidas de informação e comunicação pública é fundamental para dominar-se sua expansão e otimizar-se a administração das políticas públicas de saúde. Estudam-se neste âmbito as atividades ocorridas, a tomar e em vias de adoção, pelas autoridades da vigilância sanitária, na Argentina e no Brasil, num processo de trabalho integrado e complementar.

Palavras-chave: Pandemia. Gripe Suína. H1N1. Política pública de saúde. Propaganda e publicidade para saúde pública. Medidas preventivas. Gripe na Argentina e no Brasil.

\begin{abstract}
The H1N1 flu received level 6 of gravity and represents a pandemics in modern world. It presents changes of genetic nature and because of it, its combat and fight turns out to be complex. The establishment of adequate information and public communication methods, to clarify the situation to the population, and orient it, is fundamental, in order to dominate the expansion of this illness, and to optimize the management of health public policies. In this ambiance, this article studies what happened, measures taken and to be adopted by the authorities, and demonstrates through the case study applied to Brazil and Argentina, that they should work in an integrated and complementary manner, to fight this new flu.
\end{abstract}

Key-words: Disease. Swine flu. H1N1. Health public policy. Advertising and publicity for public health. Preventive measures. Influenza in Argentina and Brazil. 


\section{INTRODUÇÃo}

Após ter se alastrado por todos os continentes do mundo, a gripe suína foi declarada a 11 de junho de 2009 uma pandemia. A primeira a ocorrer com esse grau de robustez e periculosidade nos últimos 41 anos, segundo a OMS - Organização Mundial de Saúde, que solicitou às autoridades sanitárias e da saúde em todo o mundo que se preparem para enfrentar uma longa e extenuante batalha, assim como reforcem e qualifiquem as defesas contra um vírus agressivo e violento, cujo surto se manifesta com força ao longo do ano 2009 e possui feições e indicativos de que será detido com dificuldades.

Este artigo analisa os eventos ocorridos com a gripe suína até 16 de junho de 2009, de tal forma que os acontecimentos mais recentes não foram registrados, nem analisados e comentados.

0 marco de referência de junho 2009 é importante, porque antevíamos uma grande, firme, forte e grave expansão da gripe no Brasil e na Argentina. Não necessariamente assim pensavam e pensam as autoridades imbuídas de combater doenças, endemias e epidemias. Portanto, este documento serve como sinal vigoroso de alerta, daquilo que está por vir e pode suceder, se não forem tomadas medidas vigorosas de combate à pandemia ora instalada.

Conforme os epidemiologistas com os quais falamos e entrevistamos, a gripe suína seria "mais suave" que a normal, usual e corriqueira, que "mata mais". Ademais, seria "muito difícil diferenciar claramente uma gripe de outra, e afinal se há mortes, todas são igualmente custosas".

Sucede que a capacidade mutagênica desta nova gripe é enorme, ela representa uma novidade, e isto precisa ser bem estabelecido para e perante a população.

Portanto, não se trata de fazer Marketing da Gripe. Nem de assustar a população para que compre medicamentos e líquidos contendo álcool e anti-sépticos. Se trata de criar o anúncio adequado, a informação correta, à população, para que ela saiba como combater a gripe e não seja alvo de mais doenças e maior mortalidade.

0 que se pretende neste estudo é mostrar a virulência da gripe suína; como ela seexpande; porque se instalou firmemente no Brasil e na Argentina - que servem de estudo de caso; e quais medidas administrativas, das agências de vigilância sanitária dos dois países, merecem atenção tanto das autoridades, quanto da população.

Fazer um anúncio que seja neutro, técnico e bem esclarecido sobre uma doença que mata pessoas e as assusta, é complexo. Logo, este artigo lida com uma questão de esclarecimento ao público de uma doença, de tal sorte que conscientize; não assuste; motive a adoção de medidas sanitárias e higiênicas adequadas; e iniba a expansão além fronteiras da gripe.

Efetivamente, desde que surgiu, a gripe suína parece arrefecer-se em certas ocasiões, a ponto de praticamente desaparecer, para ressurgir mais adiante, em outros países e sob novas condições, afetando as comunidades humanas.

Neste processo, a gripe suína foi assumindo um espaço geográfico e uma dimensão crescente, de tal forma que sua presença na América Latina é confirmada e notada. Isto significa que a pandemia não é apenas objeto comum de uma significativa preocupação mundial. Para debelá-la serão necessários esforços comuns, em nível mundial. 
E para que sua minoração, erradicação e efetivo combate de fato aconteçam, será preciso que as nações tanto em nível grupal, quanto em nível individual, encontrem rapidamente os meios para tornar exeqüível e bem sucedido um programa integrado, conjunto, sistêmico, de combate à gripe suína.

Neste particular, na América do Sul, onde o papel e a representatividade do Brasil e da Argentina se destacam, é fundamental o trabalho integrado, com vistas a evitarem-se as formas de disseminação da gripe suína e alcançarem-se resultados integrados que venham a beneficiar ambos os países, assim como toda a América do Sul e o mundo. Nas seções que seguem, este corresponde ao objetivo central deste estudo.

Isto é, o Brasil e a Argentina são as maiores, mais importantes e mais destacadas sociedades da América do Sul. Pelos critérios de população total, produto interno bruto, volume de comercio e transações internacionais e fluxos de turismo, que são elementos vinculados a transporte e circulação internacional de bens, riquezas e pessoas, os dois países apresentam as mais importantes posições e estatísticas. Logo, políticas de saúde bem estruturadas pelas duas nações líderes e entre elas, podem ser decisivas para a ocorrência de sucesso no combate à pandemia presente, a pandemias que eventualmente venham a surgir no futuro e a propósitos indicativos das formas e processos de otimização de relações entre todos os países que compõem a edificante e progressista comunidade da América do Sul e do Continente Americano em geral. Vale lembrar que mudanças significativas podem ocorrer em inúmeros campos da vida humana, entre eles, o da saúde. A 20 de Maio de 2009, portanto em período sumamente recente, as agências de saúde e vigilância sanitária no mundo acreditavam que o influenza H1N1 se revelava bem menos letal do que se previa. Contudo, a situação virou em menos de um mês, para o vírus A - H1N1 mostrar sua verdadeira e crescente força, trazendo consigo o espectro da morte de dezenas de cidadãos do mundo.

Transmitido inicialmente dos suínos aos seres humanos, até Maio de 2009 ele havia se alastrado velozmente por 34 países e contaminara 7.520 pessoas, produzindo pelo menos 65 vítimas fatais.

Violento e endêmico, o processo de ataque virótico não pode ser negligenciado ou minorado. Sua disseminação é questão de dias e seus efeitos são demolidores. A Gripe comum mata pelas estimativas da OMS - Organização Mundial da Saúde, 250.000 pessoas anualmente.

Não há porque se acalmar, baixar a guarda e acreditar que o sumiço da influenza é de vez. Ela reaparece logo mais, à frente, travestida de novas feições, com energias que contorcem de dores e padecimentos fatídicos a humanidade. E os cientistas aguardam uma variante do H1N1, ou um vírus por ora totalmente desconhecido, que terá uma força devastadora.

Isto significa que todas as nações do mundo precisam cooperar entre sí, para combater este e os futuros males das influenzas que combaterão a humanidade, cuja constituição não foi desvendada por completo pela ciência, sobretudo porque a capacidade de replicação e de se modificar é exponencial. Segundo os cálculos do NESPAS - Núcleo de estudos da saúde da Previdência e da Assistência Social, existem pelo menos seis trilhões de vírus espalhados e diferentes pela natureza dos quais os centros científicos identificaram tão somente 29.725 até maio de 2009. Destes conhecidos, 836 ou 2,81\% provocam doenças e males em seres humanos.

\section{ARGENTINA E BRASIL: O CONTEXTO DA AÇÃO CONJUNTA EM SÍNTESE}


O objeto deste estudo, concentrado nas formas de combate da Influenza H1N1 na Argentina e no Brasil se justifica entre outras, pelas seguintes razões:

a) 0 Brasil e a Argentina correspondem às duas maiores extensões territoriais; possuem as duas maiores populações; detêm e mantém as duas mais ricas e dinâmicas economias; e possuem os maiores vínculos comerciais internacionais da América do Sul;

b) 0 Brasil e a Argentina conjuntamente corresponderam em 2008 a 67\% da economia da América Latina. Portanto, do ponto de vista econômico eles são sumamente representativos tanto para o subcontinente sul-americano, quanto para a comunidade latino-americana; e

c) Os dois países são os maiores e mais dinâmicos membros do MERCOSUL, o que significa que pela movimentação, emigração e transporte humanos, em função de programas educacionais e de lazer, de turismo e por razões comerciais, equivalem a aproximadamente 94\% do movimento merco-sulino total, o que permite que se entendam que medidas internas, endógenas, de cada país, associadas a medidas tomadas em conjunto, explicam em sua larga maioria o que sucede e acontecerá no MERCOSUL. E estas medidas também ajudarão os demais países membros a dotarem medidas adequadas, uma vez que pela sua dimensão, o teste da Lei dos Grandes Números (LGN) terá sido realizado e as evidências dos caminhos mais adequados a trilhar terão despontado e sido identificados sobre relações significativas, consolidadas e de montante representativo.

0 quadro-resumo 1 a seguir mostra que a pandemia também afetou e afetará duas sociedades importantes no contexto mundial, a Argentina e a do Brasil, que possuem o 8o e o $5^{\text {o maior }}$ território nacional no mundo, respectivamente, logo uma dimensão representativa, estratégica e que é uma referência mundial; populações de 39,7 e de 190 milhões de habitantes, ou seja o $31^{\text {o }}$ e o $5^{\text {o }}$ maior contingente populacional do planeta; e um

Produto Interno Bruto (PIB) oficial de US\$ 523,7 bilhões e de US\$ 1.998 bilhões, que classificam pela ótica do produto os países em $23^{\circ}$ e $8^{\circ}$ maiores produtores do mundo.

Os indicadores sociais podem ser objeto de melhoria em ambos os países, porquanto indicam algumas fragilidades nacionais, mesmo que tenham sucedido progressos notáveis nas últimas quatro décadas. As posições internacionais, comparadas a países mais desenvolvidos, indicam a possibilidade de galgar para posições ainda melhores e sugerem carências que se fazem sentir na área da saúde, objeto deste estudo, e que hão de manter naturalmente alertas aqueles que lidam com a atual pandemia de Influenza H1N1. Note-se que o IDH - Índice de Desenvolvimento Humano, composto de três indicadores - o PIB per-capita (a ser maximizado); o índice de alfabetização (a ser maximizado, vale dizer, é fundamental minimizar o índice de analfabetismo); e a expectativa de vida (em tese, se existe saúde física e mental, quanto maior, melhor) é de 0,86 para a Argentina colocando-a em 46a colocação; e a do Brasil é de 0,807 , posicionando o país em 70ํ․

Há diferenças nos indicadores entre os dois países, o que indica formas diferentes de atuar sobre os desafios, assim como histórias, contextos e valores estatísticos que convidam à solução por conta das necessidades próprias individuais e ao suceder-se o caso de um problema conjunto, como o de uma pandemia, que pede pela resolução de um assunto de interesse universal, a importância de se encontrarem métodos de planejamento e implantação de projetos de combate à influenza que considerem os denominadores comuns de valores.

A esperança de vida da Argentina é de 75,3 anos, ou o correspondente ao 59o lugar no mundo, e a dos brasileiros é de 72,7 anos, ou o 78으 lugar. Em face do Japão e da Finlândia, onde a 
expectativa de vida beira os 81 anos, ainda revelam-se progressos por fazer, embora as classes mais altas de renda nos dois países analisados possuam expectativas similares às dos dois países mais ricos, ora citados.

Problemático é a índice de mortalidade infantil, que no Brasil é de 23,6 infantes em cada mil nascidos, o que o posiciona em $90^{\circ}$ colocado; enquanto verifica-se na Argentina uma mortalidade infantil de 13,4 infantes a cada mil nascidos, ou o 125을.

Em face da Suécia, onde as estatísticas revelam 6 para cada 1000 infantes mortos, Brasil e Argentina cravam respectivamente quase 4 e 2 vezes mais óbitos o que demonstra a necessidade de se investir ainda mais em saúde, educação, assistência e fito-sanidade nacional.

Embora o grau de alfabetização seja crescente e elevado em ambos os países, de 97,2\% (55ำ lugar no mundo) e 90,4\% ( $\left.90^{\circ}\right)$, a qualidade do aprendizado deixa a desejar, especialmente no caso brasileiro.

Em conjunto, estes indicadores mostram que os dois maiores países da América do Sul progridem positivamente, na direção do desenvolvimento econômico e social e do bem-estar alicerçado sobre políticas de saúde e de educação convenientes. E que no caso da pandemia decretada em junho de 2009, ambos os países possuem no quadro geral sociedades progressistas saudáveis, bem alfabetizadas, com alta e crescente expectativa de vida, que são plenamente capazes de receber mensagens, orientações técnicas e médicas, e reagir positivamente a elas, para minimizar e reduzir as ameaças advindas de uma agressiva influenza.

Também em conjunto, os dados estatísticos revelam a significância e a representatividade das duas nações, economias e populações em conjunto. Por se tratarem de países grandes, cujo território é grande e possui significativa população, é sumamente importante que as ações na área de saúde prossigam coordenadas e harmonizadas, como estão, a favor das duas populações e do sub-continente Sul-Americano como um todo.

Quadro 1 - Dados resumo da Argentina e do Brasil

Dados resumo relevantes da Argentina e do Brasil.

\begin{tabular}{|c|c|c|}
\hline Variável & Argentina & Brasil \\
\hline Território & & \\
\hline Área em Km ${ }^{2}$ - total & $2.780 .400,42$ & $8.514 .876,59$ \\
\hline Agua (\%) & 1,12 & 0,65 \\
\hline População & & 189.985 .135 \\
\hline Estimativa de 2008 & 39.745 .613 & 169.799 .170 \\
\hline Censo de 2001 e 2000 resp & 37.282 .970 & 22,30 \\
\hline Densidade Km ${ }^{2}$ & 14,29 & 1.981 .438 \\
\hline PIB 2007 - US\$ milhões & 523.784 & $11.251,28$ \\
\hline PIB per capita 2008 & $13.778,03$ & 50,50 \\
\hline Indicadores sociais & & 0,81 \\
\hline Gini (2006) & 49,53 & 72,70 \\
\hline IDH (2006) & 0,86 & 23,62 \\
\hline Esp. De Vida & 75,30 & 90,04 \\
\hline mortalidade Infantil & 13,44 & Tropical, Subtropical \\
\hline Taxa de Alfabetização & 97,25 & Equatorial, Semi-árido. \\
\hline Clima & Temperado & \\
\hline
\end{tabular}

Fonte: Instituto Nacional de Estadística y Censos - INEC e Instituto Brasileiro de Geografia e Estatística - IBGE ; Anuários de 1985 a 2007 


\section{A FORMA DE AGIR DOS VÍRUS}

A rigor, um vírus se resume a poucos genes incluídos dentro de uma cápsula de proteínas. Ele é dos seres vivos, um dos mais simples. E possui seu modo e forma própria de agir, de se comportar, embora todos eles possuam algumas etapas, momentos e estágios que são comuns.

Sob uma ótica genérica, um processo infeccioso se inicia quando uma molécula de proteína da parte de fora de um vírus se liga e atrela a outra na superfície da célula de um ser humano. A seguir, o vírus lança na parte interna da célula uma fração de suas componentes genéticas, de tal sorte que este composto genético viral se mescla ao da célula. Subjugada, dominada, escravizada, a célula afetada passa a gerar substâncias virais na medida em que tenta produzir suas próprias proteínas. Logo, na dinâmica das transformações, a simbiose faculta e permite, dá espaço positivo, para que o vírus se replique. Neste processo, a célula hospedeira e original morre. Energizados, os vírus novos atacam mais células novas e procuram sair do organismo para se espalhar em outros seres vivos, entre eles os superiores, seres humanos.

O combate aos vírus é sumamente difícil e complicado, entre as principais e diversas razões, porque eles aprendem mediante mudanças a ser resistente e a neutralizar os efeitos de novos remédios e antídotos descobertos pela ciência. Assim, é preciso descobrir literalmente as fragilidades, os pontos fracos de cada influenza que aparece, para combatêla em sua estrutura genética e compleição mais frágil e abalável. Como há inúmeras influenzas, a cada uma corresponderá um antídoto diferente.

Ter em mente na situação emergencial e de necessidade de combate a um novo tipo de influenza que existem largos passos dados pela humanidade e pela ciência para combater o vírus, é essencial. 0 conhecimento e a experiência adquiridos permitem que se montem padrões e se disponha de referenciais. Neste sentido, o combate ao vírus influenza a - H1N1 parte de tratamentos que se conhecem, nem sempre completos, que permitem diagnosticar três elementos, pelo menos, de cada influenza, como se fará a seguir:

a) A identificação - pelo nome;

b) Os remédios e tratamentos disponíveis que representam a melhor solução atual, parcial que seja; e

c) As dificuldades encontradas, isto é, os desafios que precisam ser suplantados.

Para efeitos de exemplo e citação, contextuem-se em síntese a Dengue, muito espalhada e inserida como endêmica no espaço do Brasil; o sarampo; o vírus da AIDS ou HIV e a universal Gripe.

A Dengue, que possui entre as suas variantes a letal dengue Hemorrágica, é um flagelo acentuado no Brasil moderno. Embora tenha sido melhor combatida em 2009, seus efeitos mobilizaram todo o estado do rio de janeiro em 2008 e em seu rastro morreram dezenas de cariocas e fluminenses. Seu remédio ainda está em fase de teste e é submetido a avaliações dos efeitos sobre o sistema imunológico, pois este é que é afetado pela Dengue.

A dificuldade em combater a dengue reside na capacidade de se erradicar e eliminar seu transmissor, o ágil e zebrado mosquito oriundo da África, aedes aegypti.

O mosquito encontra fácil abrigo e espaço para reprodução nas matas e florestas tropicais, nas 
matas ciliares; nas bordas dos rios e afluentes ribeirinhos; nos lagos naturais e artificiais e em terrenos baldios assim como construções abandonadas e não vigiadas feitas pelas pessoas. Em pneus, garrafas, latas, carros sucateados e milhares de pequenos poços que se formam após as chuvas, os mosquitos encontram seu paraíso e os humanos seu suplício.

Além da vacina, portanto, é medida óbvia e fundamental a limpeza residencial, imobiliária, citadina e urbana, promovida pelos indivíduos e famílias, em consonância com a limpeza das companhias de limpeza e sanidade urbana, das prefeituras e estados.

O Sarampo possui remédio e seu combate obstinado nas últimas quatro décadas surtiu grandes efeitos no mundo e na América do Sul. Com a vacina, combate-se com eficácia o Sarampo, sendo essencial o comparecimento maciço da população, para agir e atacar em bloco contra o vírus e evitar potenciais doentes novos.

Uma boa razão para o sucesso verificado com o Sarampo erradicado praticamente, é que o vírus possui baixa taxa de mutações, logo, quem é vacinado e sobrevive é imunizado por pelo menos trinta anos.

O HIV ou originariamente AIDS, Síndrome da Imunodeficiência Adquirida, não possui cura nem remédio que o elimine. Existem positivamente coquetéis que minoram os danos e padecimentos da doença, assim como prolongam o prazo de vida dos pacientes. Os remédio vão sendo aperfeiçoados e buscam-se os anti-virais que impedem a reprodução do vírus ou inibem algum processo de infecção que atinja novas células pelas réplicas.

$\mathrm{O}$ desafio e a dificuldade no combate à AIDS reside no fato de que o HIV se mescla de tal forma com o material genético das células que formam o sistema imunológico, que se torna difícil combatê-lo sem que se danifiquem as estruturas celulares.

A Gripe é constituída de um vírus sumamente resistente e mutável. Sua capacidade de disseminação é enorme e encontra-se em todas as partes do mundo. Literalmente, a Gripe dá a volta ao mundo, através das pessoas e dos movimentos sociais, turísticos, comerciais que também trazem e levam em seu bojo o progresso da humanidade.

O remédio da Gripe é produzido a partir de versões inativas do vírus influenza, logo a vacina permite que se prepare o sistema imunológico para que se enfrente a infecção. A grande dificuldade com a qual se defronta o agente que o combate, é que essa prevenção é de eficiência diminuta porque a influenza passa por mutações sumamente rápidas, a tal ponto que os anticorpos que a vacina cria não conseguem reconhecer, identificar, o inimigoque se modificou em substância.

\section{SITUAÇÃO DA GRIPE EM JUNHO DE 2009}

Conforme as estatísticas divulgadas pela OMS - Organização mundial da saúde em Genebra no mês de junho de 2009, o alerta contra a gripe A (H1N1) alcançou a fase 6, numa escala que vai de 1 a 6. Logo, atingiu-se o nível mais alto da escala, o que fornece perfeitamente o grau de gravidade e de seriedade com o qual o assunto precisa ser tratado no mundo inteiro.

Com efeito, a gripe suína apareceu no México. Conforme as aparências, foi passada na forma de gripe humana a suínos, que por sua vez a fizeram passar aparentemente por mutações. A seguir, numa nova e letal configuração, foi repassada a humanos, que por sua vez, infectados, trataram ser voluntariedade que fosse, em repassá-la adiante. 
Sucede que em ambientes nos quais se encontram condições higiênicas e sanitárias frágeis, carentes de maior segurança em técnicas de saúde, a gripe suína encontrou condições propícias para se disseminar.

E nos tempos modernos, nos quais os meios de transporte - entre os quais notabiliza-se o aéreo - permitem a locomoção de pessoas e cargas numa velocidade inédita e crescente, integrando os continentes em questão de horas, a transmissibilidade das doenças infectocontagiosas é sumamente rápida.

Se no passado as doenças ainda eram sujeitas às precariedades dos transportes navais e fluviais, nos tempos que correm em poucas horas aviões singram os espaços aéreos internacionais e transcontinentais, de tal sorte que uma doença que ainda apareceu parcamente num país de origem e que ainda não é objeto maior de preocupação pode estar se incubando e adentrando noutras latitudes e longitudes, formando em cadeia e efeito dominó uma miríade de outras localidades sujeitas a infecções, problemas de saúde e políticas que permitam os seus combates efetivos e eficazes.

Deste modo, a considerar-se a data de 11 de junho, 74 países confirmaram o surto de gripe suína em seu território, com 28.974 casos registrados e confirmados. Tão e mais grave ainda, pelo menos 144 mortes foram confirmadas.

Isto significa que para cada 201,21 registros confirmados de gripe suína, existe uma fatalidade. Esta taxa de mortalidade pode ser considerada bem elevada, na medida em que uma vez contraída $0,5 \%$ da população a ela sucumbe, ou analisado de outra forma, conforme as estatísticas de mortalidade divulgadas pelas instituições públicas de geografia e demografia, aproximadamente se verificam 5 mortes, para cada 1.000 casos registrados e confirmados da infecção.

Para os tempos atuais esta é uma taxa de mortalidade moderada. Contudo, isto não significa que a H1N1 vá permanecer como está. Por mutações, sua força e capacidade de devastação podem mudar na direção de maior mortalidade, logo, ela não apenas preocupa pela força que mostra. Ela também pode se transformar no futuro numa gripe mais poderosa, cuja base de destruição está sendo demonstrada. Existe, portanto e, sobretudo um indicativo importante da força potencialmente devastadora que o $\mathrm{H} 1 \mathrm{~N} 1$ poderá ter, se não for controlado e erradicado.

Não existe seguro para afirmar-se que esta moderação será contínua e permanente. As estatísticas podem no início aparentar índices de letalidade baixos ou nulos, com o súbito surgimento de alta e exponencial morbidade.

Por esta razão, estar alerta e consciente da doença e de sua capacidade de expansão é vital, mas insuficiente. Precisam-se gerar instrumentos sanitários, laboratoriais, espaciais e tecnológicos, para lidar com a gripe, que permitam em tempo real o conhecimento de sua evolução e caracterização perante a população.

Como a gripe admite mutações, e para configurações vivas ainda mais agressivas que as atualmente verificadas, o potencial de devastação da gripe suína é elevado e não há de ser em hipótese alguma menosprezado.

A medida do nível 6 não se relaciona ao aumento da gravidade da gripe suína, ou ao número de mortes. 0 nível 6 é dado em função da velocidade e da capacidade de expansão do vírus em 
pouco mais de cinco meses.

O vírus é transmissível com facilidade de uma pessoa para outra, e de um país para outro. Com o anúncio e acompanhamento dado pela OMS, passa-se de um estado de emergência, para um superior e mais complexo, que é o de combate em longo prazo. Isto significa que a pandemia da gripe suína permanecerá incubada e estorvando a humanidade por pelo menos seis meses e é bem capaz que se mantenha por vários anos.

Os trabalhos de combate à pandemia começam na terra, no país, no ambiente de cada um. E se o trabalho em território próprio for bem empreendido, ao menos meio caminho estará sendo empreendido para que se debele mais esse "mal do século".

Os meses de março e abril de 2009 agregaram à profunda crise econômica mundial mais uma variável preocupante e séria, a saber, a gripe suína originária do México, onde mais de 150 pessoas teriam morrido em pouco mais de 40 dias.

Ondas de gripe e ameaças locais e mundiais à saúde são um evento que se repete, embora sejam imprevisíveis em seus surtos, conseqüências, duração e dimensão.

Embora a OMS - Organização Mundial de Saúde entenda que esta gripe suína esteja em fase de redução e aparente desaparecimento, logo seus efeitos no futuro possam simplesmente desaparecer ou serem cada vez mais fracas, as sociedades hão de permanecer vigilantes, atentas e preparadas.

Isto, porque ao desaparecer, a gripe dá uma trégua em seu ataque contra a humanidade. Mas não foi curada nem tampouco debelada. Não ocorreu um controle da gripe, seu isolamento e sua aniquilação. Logo, os agentes patógenos que podem afetar as populações permanecem no ar. E pode reaparecer, seja em sua roupagem atual, seja numa nova variante, mais forte e letal, que pode ameaçar e matar mais cidadãos do mundo.

A humanidade tem sido cada vez mais zelosa e cuidadosa com doenças transmissíveis, e não é para menos. Vive ela cada vez mais em maiores aglomerados humanos, nos quais a concentração de habitantes por kilômetro quadrado aumenta. As pessoas se espremem em metrópoles e criam para si mesmas um ambiente propício à propagação rápida de doenças, a menos que exista uma política pública de saúde eficaz.

Várias doenças transmissíveis chegam às cidades devido às transformações causadas pelo homem no campo, nas florestas, e nas vegetações equatoriais e subtropicais.

Os roedores e as aves, ao não possuírem mais espaço para viver em seus hábitats naturais acabam se encontrando mais amiúde com o homem, ao qual transmitem doenças novas, e outras, outrora confinadas às áreas em que moravam sem a invasão humana.

Nos últimos vinte anos, são conhecidos e assustadores os surtos de Ebola na África; de Hantavirus na América do Sul e de gripe aviária gerada por marrecas chinesas na Ásia.

E mais assustadores ainda são os meios de propagação dessas doenças. No mundo moderno, as doenças transmissíveis viajam de avião de um continente para outro em questão de horas. Logo, contaminar o mundo é questão de um dia, se não for de dias ou poucas semanas.

Isto gera um efeito novo: o efeito supersônico de contaminação global. E se ele não tiver antídoto, não possuir meios para ser bem identificado e debelado, torna-se potencial e 
efetivamente mortal e grave para a saúde geral, universal, da humanidade.

Eis porque, faz sentido classificar as epidemias, as pandemias, os surtos, os acontecimentos bacteriais e viróticos com graus que variam de 1 a 6, para indicar-se o grau de preocupação, transmissibilidade e perigo que se corre com essas epidemias, influenzas e similares. No grau atual da gripe suína, de 6 pontos, vive-se um estado bem mais grave que o de um sinal de alerta. As evidências de mortes significam que a doença está fora de controle. Logo, viajar aos locais nos quais a doença provavelmente se originou não é recomendável e pode implicar na repetição de maiores ondas de transmissão.

Certamente, estamos bem distantes da peste negra que assolou a Europa na Idade Média e na Alta Idade Média, quando a população européia se viu reduzida para 2/3 da original. Isto é, $33 \%$ de fatalidades sucederam, deixando cidades, vilas e vilarejos inteiros vazios, literalmente às moscas e, sobretudo, invadidas por pulgas, as transmissoras efetivas da peste pela via dos ratos. E também estamos afastados da devastadora gripe espanhola, que dizimou segundo as estimativas de 22 a 40 milhões de pessoas no mundo, no século XX, pelos idos dos anos 1918 a 1920. Em São Paulo, a maior metrópole do Brasil nos tempos correntes e a segunda maior cidade brasileira na década de 1930, logo após a capital e cidade do Rio de Janeiro, calcula-se que morreram 33.500 pessoas pelo menos, da citada gripe, de tal sorte que famílias inteiras desapareceram de bairros tradicionais e aonde os imigrantes, chegando por navios, aportavam.

Além da Gripe Espanhola outras duas pandemias de influenza marcaram o mundo no século XX: a Gripe Asiática de 1957 - 1960 e a Gripe de Hong-Kong de 1968 - 1972.

0 vírus da influenza aviária, conhecido por $\mathrm{H} 5 \mathrm{~N} 1$, fortemente patogênico, foi transmitido diretamente por aves aos seres humanos. Patos, frangos, gansos e aviáceos em geral viraram alvo de grande preocupação, principalmente nos países do Sudeste Asiático, onde a população possui grande convívio e faz vasto pastoreio de aves, em granjas, arrozais, e freqüentemente em ambientes fechados, logo tem intensa interação com aves.

Houve a ocorrência de pelo menos 180 casos delicados de gripe aviária em humanos, e 103 no mínimo evoluíram para morte.

Portanto, as preocupações com a saúde pública, à luz da experiência mundial, e histórica, estão e são bem fundamentadas. Contaminações podem adquirir uma velocidade grande e se tornarem em literais hecatombes, caso não sejam controladas e aniquiladas na fonte.

A humanidade há de se precaver. Aliás, o termo hecatombe vem do grego e sugere a soma de duas palavras: cem, de heca; e tombe, ou tumba, ou sepulcro, logo onde se enterram os mortos. Nos idos do grande Império Grego, Helênico, 2.500 anos atrás, 100 mortos ou mais representavam potencialmente uma parte significativa de uma população humana. Na França, em francês, tomber significa cair. Logo, também seria possível fazer uma alusão aos "100 que caem".

Logo, ao menor sinal de alerta, é preciso avisar e dispor das providências necessárias. Com a população avisada e guarnecida, os riscos de transmissão caem e a sociedade local se assegura um índice de sobrevida maior.

Este aviso, este alerta, envolve comunicação e marketing público. Isto é, as autoridades sanitárias necessitam utilizar os instrumentos de comunicação para aviso aos consumidores de saúde (a população total) sobre os flagelos gerados pela gripe H1N1 e sobre como lidar 
com ela.

Vale a pena nos questionarmos se estamos de fato preparados na plenitude para as doenças transmissíveis em nível internacional. Nossa rede de hospitais públicos, de clínicas e de prontos-socorros está habilitada a enfrentar alguma pandemia mais séria?

Pelas evidências, Brasil e Argentina se preocupam com o assunto, possuem planos de combate à influenza, e a OMS - Organização Mundial da Saúde reconhece que ambos os países possuem maturidade e preparo para combater e neutralizar o vírus. Não que o caminho seja fácil, sem percalços ou livre de críticas e pontos de estrangulamento, o que é natural (Vide: América do Sul está preparada para a Gripe, diz OMS).

No Brasil, o assunto é comandado com clareza pelo Ministério da Saúde, que possui um detalhado e disponível a toda a população mundial e brasileira Plano Brasileiro de Preparação para uma Pandemia de Influenza - 3@ versão. E o Ministério da Saúde recomenda a todos os estados da União o estado de alerta, a atualização de metodologias de combate a toda e qualquer ameaça de saúde pública que aparece, e ao dever de elaborar-se em todo estado um Plano Estadual para enfrentamento de possível pandemia de Gripe, Influenza.

Este plano orienta as ações e as atividades entendidas como necessárias para impedir, erradicar, minimizar, combater e certamente retardar a introdução da influenza no Brasil, com a minimização de doentes e de óbitos.

Os estados da União, atentos e observadores da demanda e orientação pública federal, possuem e fazem seus planos e é fácil obtê-los na íntegra. Basta entrar na Internet, nas secretarias de saúde estadual, e dar download nos planos antiinfluenza estaduais. Eles são bem claros, detalhados e a eles se acoplam outras políticas, orientações e informações complementares, que mostram existir um movimento de treinamento, educação e comunicação entre os servidores federais, estaduais e municipais, contínuo, no que diz respeito a ações e vigilância sobre influenza.

Na Argentina, existe a preocupação e ação do Ministério de la Salud, que publicou e renova o Plan Nacional de Preparación para uma pandemia de influenza (2009). A estrutura participativa é ampla, com atuação conjunta de órgãos relevantes, como a Secretaria de Promoción y Programas Sanitários; a Subsecretaria de Prevención y Control de Riesgos; a Dirección Nacional de Emergências sanitárias - DINESA; a Dirección Nacional de Prevención de Enfermedades y Riesgos; a Dirección de Epidemiologia; A Dirección Nacional de Programas Sanitários - DNPS; e no caso das bilateralidades interfronteiriças, conta-se também com a Sub-Secretaria de Políticas, Regulación, y Fiscalización e a Dirección de Regulación, Fiscalización y Sanidad de Fronteras.

Tal como no Brasil, os órgãos adicionais são numerosos e existem agentes e instituiçõesespelho, similares, para dar vazão a tantos e numerosos serviços que se fazem necessários para dar a verdadeira segurança em saúde pública. Mesmo que com a possibilidade involuntária de se omitir alguma entidade, também possuem envolvimento com campanhas de combate da influenza, a Administración Nacional de Laboratórios e Institutos de Salud ANLIS, Dr. Carlos G. Malbrán; o Instituto Nacional de Enfermedades Infecciosas Carlos G. Malbrán, ora assuntado; o Instituto Nacional de Epidemiologia - INE - Juan H. Jara; o Instituto Nacional de Enfermedades Respiratórias Emilio Coni - INER.

No processo transversal de integração de políticas públicas, assunto vital para a correta ação pública, várias instituições similares se somam nos esforços, tal e qual no Brasil. Existe, pois 
um paralelismo no processo arquitetônico e construtivista de tratar da saúde Pública e de se estruturar o Estado para fazer face às demandas variadas, esperadas e inesperadas, da saúde.

Isto inclui o Ministério Del Interior; o Instituto Nacional de Servicios Sociales para Jubilados y Pensionados - PAMI; a Facultad de Medicina Universidad nacional de Córdoba, Instituto de Virología J. Vanella; e o Servicio Nacional de Sanidad y Calidad Agroalimentaria - SENASA Dirección Nacional de Sanidad Animal.

O plano argentino de saúde e combate a pandemias possui uma estruturação clara e fácil de entender, didática, compondo-se de quatro seções, a saber: geral; normativa e executiva; operacional e de procedimentos.

O plano brasileiro possui oito capítulos e antes abre espaço para a apresentação de objetivos. Vem então os capítulos: o risco de uma nova pandemia de influenza (1); a vigilância da influenza humana (2); diagnóstico laboratorial do vírus influenza (3); ações de imunização (4); vigilância sanitária de portos, aeroportos, fronteira e recintos alfandegados (5); a atenção à saúde (6); planejamento de comunicação do governo federal (7); e aspectos jurídicos (8).

Rico, bem detalhado e escrito com clareza, o documento é um eixo de orientação federal, que serve de referência às ações estaduais.

Particularmente interessante é a seção das "estimativas globais do número de pessoas suscetíveis e ocorrência de formas graves de influenza derivadas do modelo estático", na qual entende-se que eventualmente toda a população poderá se expor ao vírus da gripe e então de 20 a 30\% dela poderá desenvolver casos clínicos de gripe, o que geraria entre 35 a 67 milhões de casos de gripe uma vez completada e encerrada a pandemia. E um quadro (pg. 25) estima eventos por faixa etária, ao considerar a totalidade de população do país em risco, por cenários pessimista (de exposição, doença, infecção e óbitos, máxima); intermediária (mediana), com também seus casos, complicações e problemas doentes graves; e otimista, onde o número de doentes é mínimo.

0 quadro 2 a seguir resume estas estimativas do Ministério da Saúde, que revela que num cenário pessimista podem chegar a 4.394 .889 os casos graves, logo aqueles que incluem morte, óbito, na população. A projeção proclama que in-extremis, pessimisticamente, aproximadamente $2,28 \%$ da população poderia vir a falecer.

Quadro 2 - Estimativas de casos clínicos de gripe e complicações Estimativas de casos clínicos de gripe e complicações na população.

\begin{tabular}{|c|c|c|c|}
\hline Suposiçáo & Casos & Complicaçóes & Graves \\
\hline Otimista & 35.208 .997 & 3.058 .832 & 205.057 \\
\hline Intermediária & 46.690 .920 & 6.639 .921 & 894.773 \\
\hline Pessimista & 67.328 .839 & 16.344 .894 & 4.394 .889 \\
\hline
\end{tabular}

Fonte: Ministério da Saúde, 2009

É apresentada uma suposição adicional importante, no que diz respeito à taxa de hospitalização de casos que se fazem complicados, mostrada por faixas de idade em dias, tal como segue no próximo quadro, 3, Taxa de Hospitalização. 
Quadro 3 - Taxa de hospitalização de casos complicados

Taxa de hospitalização de casos complicados.

\begin{tabular}{|l|c|c|c|c|}
\cline { 2 - 5 } & \multicolumn{4}{c|}{ anos } \\
\hline Taxa de Hospitalização (\%) & 0 a 2 & 3 a 14 & 15 a 59 & 60 ou mais \\
\hline Grupo de Baixo Risco & 10 a 30 & 5 a 10 & 5 a 10 & 10 a 30 \\
\hline Grupo de Alto Risco & 20 a 50 & 10 a 30 & 10 a 30 & 20 a 50 \\
\hline
\end{tabular}

Fonte: Ministério da Saúde, 2009

Deste modo, uma pandemia severa possuiria significativos impactos sobre a sociedade brasileira, que mostra grande esforço público em se organizar na área da saúde, para conseguir atender as necessidades que se fizerem necessárias. Isto também implica na disponibilidade de ministérios, órgãos e entidades de saúde, disponíveis e preparados, atuando com a iniciativa privada, para fazer em face de eventuais ataques da influenza.

Somando-se ao Ministério da Saúde, que comanda o SUS, o Sistema Único de Saúde, o Brasil tem entre outros, institutos grandes, de nível internacional e sério de saúde, como a Fundação Oswaldo Cruz, o Instituto Vital Brasil, e o Butantã, onde vacinas são produzidas e tem salvado vidas realmente. Mas, estamos preparados para uma gripe suína? E a rede de hospitais públicos, que pena com um orçamento erodido e relativamente limitado para as necessidades que a população pobre e desassistida apresenta, seria capaz de fazer face a uma influenza mais forte, que afetasse milhões de pessoas?

Mais recentemente, o orçamento, a dotação orçamentária destinada pelo governo federal ao Ministério da Saúde vem crescendo e aumentando. Esta é uma medida oportuna e necessária, condizente com o que se espera de ações públicas a favor da sociedade civil. Todavia, a demanda reprimida existe e falta melhor alocação de recursos. Se Gasta muito em administração e bem menos em prevenção e cura em regime operacional.

E neste processo dinâmico, a vigilância para evitar e minimizar o ataque do vírus influenza é crescente e se faz sentir na sociedade.

Em 2000, o Ministério da Saúde começou a implantar um Sistema de Vigilância da Influenza em todo o território nacional, com o objetivo de acompanhar e fiscalizar as cepas dos vírus influenza que transitam pelos estados brasileiros; responder a situações imprevistas e que fogem ao normal, cotidiano, usual; avaliar os efeitos de campanhas de vacinação contra a doença; dar follow-up à tendência de morbidade e mortalidade; e divulgar, comunicar informações epidemiológicas.

O Sistema de Vigilância da Influenza é tal, que ele "prevê a detecção, a notificação, e o controle de surtos independentes da rede sentinela, em consonância com as normas atuais sobre notificação de doenças transmissíveis no país" (in: Processo de Implantação da Vigilância Epidemiológica da Influenza em mato Grosso).

\section{FATORES DETERMINANTES DA GRIPE SUÍNA - INFLUENZA A - H1N1}

Uma questão central sobre a infecção que aflige o mundo no ano de 2009 é associado ao fato de se determinar quais são os fatores determinantes que explicam a existência e o aparecimento, fortalecimento ou enfraquecimento, da Gripe Suína.

É sabido que a Gripe Suína surgiu do estabelecimento de uma relação de transmissão entre 
seres humanos e suínos, no México. E essa transmissão acontece pelo ar, com a disseminação do vírus de uma pessoa para um animal, e de um animal para uma pessoa. Feita a mudança mutagênica, a transmissão se sucede de pessoa para pessoa.

Contudo, uma vez estabelecida a existência da Gripe Suína, não é suficiente registrá-la e conviver com sua estatísticas de cura e morbidade. É fundamental dispor dos elementos que a determinam e explicam. Uma vez que é determinado e identificado convenientemente o conjunto de elementos que explicam porque, onde, em que circunstancias e de que forma surgiu a pandemia e sobretudo a cepa que a gerou, pode-se buscar formas científicas de se resolver a doença, com o conveniente remédio, antídoto, dito anti-viral, assim como mediante a adoção das medidas de gestão pública, da saúde, que se fizerem necessárias.

0 quadro que segue apresenta os fatores determinantes principais e que são associados a uma cepa pandêmica. Logo, é de se esperar que eles sejam o equivalente a variáveis independentes, que afetam a variável dependente, a Gripe Suína neste caso.

A escolha adequada e correta do conjunto ou cesta de variáveis explicativas da Gripe Suína permite mediante modelos e métodos de regressão múltipla e estatística avançada que se defina o peso (grau de correlação) e a significância estatística, na explicação da evolução intertemporal da Gripe Suína.

Neste estudo, chega-se até o ponto do levantamento das variáveis presumidamente determinantes da Gripe Suína. Elas são fruto do levantamento deste autor no NESPAS - o Núcleo de estudos da saúde, da previdência e da Assistência Social, na EBAPE / FGV e de levantamentos da equipe da IBCI - Diretoria de Pesquisas. Pode haver naturalmente outros fatores determinantes a considerar, da Gripe Suína e da Pandemia. Contudo, acredita-se que uma vez usado o método Delphi, que aproveitou o conhecimento e a experiência de campo apresentada por 63 analistas e cientistas vinculados ao NESPAS, o dimensionamento determinístico da função explicativa da Gripe Suína foi estabelecido com o devido rigor e elevada significância estatística básica. 0 quadro 4 a seguir apresenta as variáveis determinantes. Em etapa mais adiantada do trabalho, pretende-se medir estatisticamente a aderência a estas suposições com as variáveis determinantes. 


\section{Quadro 4 - Principais Fatores Determinantes e Explicativos da Disseminação de uma cepa}

Principais Fatores Determinantes e Associados à Disseminação de uma Cepa Pandêmica.

Patogenicidade da nova cepa.

Virulência e agressividade da nova cepa.

Velocidade de disseminaçăo da nova cepa.

Capacidade da comunidade e das pessoas de reagir e sobrepor-se à nova cepa, por açöes comjuntas de ordem sanitária, infra-estrutural, educacional e afins.

Grau de eficiência da transmissăo do agente infeccioso.

Grau de imunidade à nova cepa, pela populaçăo que é atacada por ela.

Grau de contato efetivo. Direto ou indireto. Raro ou numeroso. Com baixa ou alta frequência. Regularmente ou irregularmente (fenômeno de sazonalidade a considerar).

Capacidade, preparo e apoio recebido pelas autoridades de saúde pública e seus colaboradores.

Competência das lideranças governamentais e capacidade de tomarem as decisōes na hora certa, com as pessoas adequadas para cada funçăo, e a infra-estrutura adequada que veio e vem sendo montada e mantida.

Capacidade de entendimento do que se passa e das medidas imediatas que precisam ser tomadas, por todos os níveis hierarquicos, da área pública e privada.

Grau de entendimento e de abertura da sociedade, para tratar claramente e sem censuras problemas de saúde e quaisquer questōes graves, que possam afetar a sociedade.

Maturidade das lideranças, para abrirem e disseminarem as informaçōes, verdadeiras, tal como elas săo, vistas como um bem público para erradicar um mal ao público.

Nivel e capacidade científica de lidar com a nova cepa. Capacidade de identificaçăo da cepa; capacidade de isolar os fatores geradores da infecção, da doença e de identificar remédios e antídotos em tempo hábil.

Capacidade de transitar dos cientistas e vigilantes, nos países e nos principais centros do mundo, para troca de informaçōes e experiências; geraçăo de modelos de cura e tratamento; configuração química, genética, biogenética, de biosegurança, e científico laboratorial, para gerar os remédios acertados.

Existência de uma cultura pró-tratamento, ou năo, pautada nas evidências da Ciência.

Mudanças climáticas, ecológicas e ambientais significativas geram novas cepas.

Mudanças urbanas, rurais, territoriais, habitacionais de humanos e animais alteram ambientes.

Fonte: NESPAS / EBAPE / FGV

Uma vez especificados, identificados e confirmados os fatores determinantes de uma nova cepa e de uma pandemia, é de se esperar que existam medidas e objetivos específicos que permitam o combate organizado à ameaça que ameaça a humanidade e cada país.

Neste sentido e nível, é se de desejar e esperar que cada país e grupo de países afeito a uma mesma dimensão territorial, tal como o sub-continente sul-americano, no qual se notabilizam e localizam a Argentina e o Brasil, empreendam medidas que derrotem o vetor nocivo, a nova cepa. Isto implica na definição clara de objetivos relacionados à derrota e eliminação da nova cepa, assim como de medidas de saúde que eliminem as oportunidades e chances de sua disseminação e permanência.

Quanto mais eficientes, eficazes e efetivas forem as múltiplas medidas que se tomarem para atacar e eliminar a nova cepa que atemoriza a humanidade e afeta evidentemente a comunidade argentino-brasileira, dado naturalmente o foco deste estudo, tanto melhores serão as probabilidades de eliminá-la com rapidez e se evitarem os custos de morbidade e intranqüilização da sociedade, gerados pela atual pandemia.

0 quadro 5 a seguir resume os que podem ser entendidos como objetivos específicos de um plano de ataque à nova cepa, para sair com sucesso do empreendimento de erradicação urgente da pandemia. 
Quadro 5 - Objetivos específicos associados ao combate das pandemias

\section{Objetivos Especificos Associados ao combate da Pandemia.}

Evitar novas cepas na medida do possivel e manter, desenvolver, as medidas sanitárias, profilaticas e de entendimentos mundiais e multilaterais, possiveis.

No caso de aparecimento de novas cepas e ameaças, identificá-las com rapidez centificismo, Iaboratorialmente e acionar todas as indicativas de segurança local e mundial, dentro dos padrōes da OMS.

No caso da expansăo e confrmaçăo de existência de uma nova cepa agressiva, virulenta, matadora, que se expande sem facilidade de controle e se dissemina rápidamente, acionar todos os mecanismos que assegurem sua expansăo retardada, limitada e cercada a ambientes cada vez mais e melhor controlados.

Divulgar e comunicar à larga, em todas as esferas, a cepa e suas características, em moldes sérios, seguros, firmes e sem alardes.

Utilizar de imediato os planos de açăo e combate a pandemias, influenzas e correlatos, para minimizar os efeitos da influenza em expansăo.

Retardar a disseminaçăo da cepa pandêmica H1N1 e afastá-la da populaçâo.

Ddar meios à populaçăo sadia para que fique sadia e Ionge da populaçăo afetada.

Se preciso, isolar quem e quantos forem suspeitos e efetiv amente infectados.

Reduzir a morbidade, em especial das formas graves da cepa que gera mais doenças e mortes por influenza.

Fortalecer estruturas de gestăo e atuaçăo direta em influenza para enfrentar a emergência epidemiológica, o que inclui a vigilância epidemiológica, o diagnóstico laboratorial, a assistência, a vacinaçăo em massa, a provisăo de novos estoques de vacina e matérias primas essenciais, e a comunicaçăo.

Identificar os maiores focos de infecçäo.

identificar localidades, comunidades e indivíduos que necessitem de tratamentos prioritários, mais urgentes, mais intensos e afins.

Identificar os grupos de quimioprofilaxa prioritária, de vacinação imediata - como as equipes envolvidas em tratamento e médicos / enfermeiros diretamente ligados a pacientes; autoridades; cientistas e outros.

Desenvolver com firmeza mecanismos de cooperaçăo bilateral Argentina e Brasil com excel encia em articulaçăo técnica e forte participaçăo da Vigilância Sanitária e das Equipes de Alerta, Fiscalização e Atenção à Saúde Pública de Estados, Municípios, Províncias, e distritos.

Fonte: NESPAS / EBAPE / FGV

\section{O QUADRO DA GRIPE SUÍNA NA ARGENTINA}

A 16 de junho de 2009 o governo argentino confirmou que quatro mortes no total haviam acontecido, causadas pelo vírus A (H1N1).

Uma das vítimas, que teve seu caso descrito, foi um jovem de 28 anos que fora submetido a um complexo transplante de medula óssea e internara-se em hospital da cidade de La Plata, capital da Província de Buenos Aires. Outra morte sucedeu na capital Argentina, Buenos Aires.

Conforme os dados divulgados pelo Ministério da Saúde, existiam na citada data 871 casos identificados de gripe suína na Argentina. Ademais, outros 993 casos potencialmente do tipo H1N1 estavam por serem confirmados, o que revelaria um máximo simultâneo de 1864 ocorrências, numa manifesta indicação de penetração da pandemia no país e em seus centros populacionais mais densamente habitados.

Ao penetrar nos bairros mais pobres, despojados e humildes, ou ao segundo cordão, assim definido, os riscos de disseminação da doença se alastraram geometricamente, pela precariedade das localidades e habitações; pela falta de informações da população sobre a pandemia e suas formas de identificação e combate; e pela carência de recursos para serem 
tomadas providências fitossanitárias múltiplas velozes e adequadas ao momento vivido.

Observa-se a existência de uma circulação virótica mais bem comunitária. Como conseqüência, para evitar um alastramento ainda maior e veloz da pandemia, diversas medidas de bom senso e uso comum universal foram tomadas, entre elas destacando-se o fechamento de colégios e de unidades de aglomeração social nas quais houve a confirmação da gripe suína.

Seria percepção corrente de analistas o fato de que as autoridades "acordaram tardiamente à extensão e à potência devastadora da nova gripe". Deste modo, ela teria se espalhado com maior facilidade, a ponto de expor as autoridades públicas a forte pressão social.

\section{O QUADRO DA GRIPE SUÍNA NO BRASIL}

A administração em situação de gravidade crescente e de emergência do ataque efetuado sobre o Brasil pelo vírus H1N1 configurou-se evidente a 16 de junho de 2009, quando o Ministério da Saúde confirmou outros cinco casos adicionais de gripe suína.

Dois destes registros são de estudantes da UDESC - Universidade Estadual de Santa Catarina, que retornaram de uma temporada de uma semana na Argentina.

Os laços e as relações entre brasileiros e argentinos são tradicionais e seculares, posto que as nações irmãs possuem excelente convívio, historicamente. E entre eles, também se destaca o existente entre argentinos e catarinenses. Assim como os catarinenses privilegiam e apreciam como um de seus três principais pontos de turismo a Argentina, os argentinos revelam possuir no Estado de Santa Catarina e suas praias um de seus quatro principais e mais desejados destinos.

Nesta movimentada relação, que em meses de férias entre janeiro e março de cada ano chega a movimentar uma leva de 270.000 argentinos e 120.000 catarinenses, em função de movimentos verificados nas condições econômicas, cambiais, comerciais e de renda, estima-se que a migração-cruzada movimente em fases de pico mensal 390.000 pessoas e na média 132.700 argentinos e catarinenses. Esta cifra mostra bem o quão vigoroso é o movimento internacional com destinos certos entre Argentina e Santa Catarina, e estimulam um foco analítico para administrarem-se corretamente os fluxos e movimentos de pessoas, automóveis, bens e serviços entre as duas regiões.

Havendo uma região afetada pelo vírus, a probabilidade da outra receber a doença transmissível em fases de veraneio é elevada e preocupante, merecendo atenção e esquemas de controle sanitário especiais, feitos sob medida, pelo tempo que for necessário. No total confirmou o Ministério da Saúde 79 casos até junho de 2009, um valor considerado baixo e tranqüilizante, dada a dimensão da população de doentes em relação à população total.

Na nossa visão, estes valores são sumamente baixos e dificilmente espelham o quadro real. É bem possível que cedo as estatísticas "explodam", mostrando crescente nível de mortalidade. Isto se deve a três fatores, a saber:

1) Existem dificuldades em detectar a gripe H1N1 como ela é, posto que carecem exames laboratoriais com kits precisos para detectar a gripe suína. Lançam-se os dados em "gripe", genericamente, o que induz a um erro de subavaliação da realidade existente e por enfrentar;

2) A doença é mais do que latente e apenas "importada por transeuntes, portadores do 
exterior", no Brasil. Ela já teve tempo para assentar-se e tomar forma. Logo, sua capacidade de expansão aumenta ao já estar aninhada no país;

3) A consciência da comunidade gerará pressões para que se diferencie entre gripes, com o passar do tempo. Frisamos que a dita "explosão" não é necessariamente permanente, nem vigorosa. Ela pode ser temporária e assumir um quadro similar ao de uma ascensão que se acomoda mais adiante num patamar. Resta, a saber, se isto é o que sucederá, quando, e qual será se existente, o patamar.

Outrossim, o Ministério da Saúde informou dispor de um estoque estratégico de 6.250 tratamentos adultos e 6.250 outros que são pediátricos, para tratar de casos de influenza A H1N1. Ademais, existem em tonéis acondicionados, 9 milhões de tratamentos em matérias primas utilizáveis de imediato. 0 medicamento em estado bruto está pronto para ser transformado a qualquer hora em cápsulas e o inicio do processamento é indicado pelo Ministério da Saúde, em função da necessidade e do vigor da infecção.

\section{PROBABILIDADE DE OCORRÊNCIA DE MUTAÇÃO DA GRIPE SUÍNA NO BRASIL E NA ARGENTINA E SEUS EFEITOS PRESUMIDOS}

As suspeitas de que poderia ocorrer uma mutação da Gripe Suína alhures, fora da sua zona original de concepção e nascimento mexicana, se confirmaram entre outros, no Brasil, a meados de junho de 2009.

E assim como a mutação foi confirmada no Brasil, ela poderá suceder em todo outro lugar, com tanto que as condições e o ambiente se apresentem propícios ao desenvolvimento e expansão da doença. Isto inclui evidentemente a possibilidade de ocorrência de vírus influenzas mutantes A com novas denominações, inclusive na Argentina.

Portanto, toda atenção e profilaxia são poucas e insuficientes, a considerar-se a velocidade e a agressividade de expansão da doença.

Segundo os pesquisadores do prestigioso Instituto Adolfo Lutz, de São Paulo, o vírus influenza A H1N1 possui uma versão brasileira, porque houve mutação na proteína hemaglutinina, que é associada à capacidade que o vírus possui em infectar as células humanas. Por ser detectada em São Paulo, o mais rico e populoso estado do Brasil, a gripe foi batizada de Influenza A / São Paulo / H1N1.

Ao encontrar-se na maior metrópole do Brasil, que se conecta com o mundo e todos os continentes diariamente, assim como com a metrópole de Buenos Aires, estão dadas as condições de transferência de novas versões do H1N1 ao mundo, a partir de São Paulo e da América do Sul.

Como ainda não se conhecia até a presente data a agressividade desta influenza mutante, identificada em abril, seu acompanhamento e evolução pelas autoridades de Saúde estabelecidas se tornou de grande e suma importância, para controle de disseminação e busca de remédios antivirais de eficácia elevada.

Observe-se que a variante do vírus paulista possui uma pequena diferença em comparação com o vírus que foi isolado no Estado da Califórnia, nos EUA, e que foi o primeiro a ser isolado no mundo desde o aparecimento e a eclosão universal da gripe suína.

Estão credenciados no Brasil pela OMS como centros de referência para o monitoramento e 
otimização de todas as etapas e ações em que implique e que incluam o combate à influenza, institutos altamente qualificados, a saber:

- Instituto Evandro Chagas 9IEC/ SVS/(MS);

- Instituto Adolfo Lutz (IAL/SP); e

- Instituto Oswaldo Cruz (FioCruz / RJ).

No nível estadual os denominados LACEN's se incluem e fazem parte da rede dita nacional, e são responsáveis pelas atividades laboratoriais; pela ação junto aos órgãos de vigilância epidemiológica; e ao monitoramento associado ao Sistema Nacional de Informação da Gripe também conhecido pela alcunha de SIVEP-Gripe.

Dada a velocidade das mudanças no campo virótico, o que é importante é encontrarem-se formas de se estancar, dominar e eliminar a pandemia, com suas variantes viróticas. Até porque não é a origem ou apenas o tipo que interessam: é o fato de que muitas pessoas viajam mundo afora e podem ter pego o vírus em outro continente, sendo ele nesta localidade passível de ter sofrido uma mutação. Donde, a importação mediante incubação latente de influenza nos passageiros que se transportam continuamente, é altamente passível de ocorrer.

Uma vez detectadas as variantes, sejam do Brasil, sejam da Argentina se confirmados novos casos, será preciso alertar imediatamente as autoridades; as unidades de vigilância sanitária; as unidades laboratoriais e de pesquisa, assim como de produção de vacinas antiviróticas, para entendê-las e produzir vacinas que se ofertem em suficiência para acabar com a influenza.

Note-se que no Brasil o ato de se ter isolado o vírus H1N1; identificado ele; e relacionado toda a seqüência genética é um feito memorável e sumamente importante, porque inédito e pioneiro. Como grande e respeitável centro de pesquisa que é, o Instituto Adolfo Lutz investe na descoberta dos processos de combate à influenza e pode representar um elo fundamental no espaço científico, da pesquisa e da saúde entre o Brasil e a Argentina, assim como toda a América do Sul, para aperfeiçoarem-se os mecanismos de identificação e tratamento de doenças contagiosas.

\section{COMO AS PANDEMIAS AFETAM A ECONOMIA}

É por compreensível e correta razão que as bolsas caem quando se confirmam influenzas e doenças mais ameaçadoras. Primeiro, porque quando se confirma a possibilidade de uma pandemia, a taxa de mortalidade pode disparar. Até onde ela pode ir, não se sabe, mas o passado relata experiências negativas. A perda de população significa a perda inestimável de vidas humanas. Logo, a sociedade perde como um todo. Segundo, porque a perda de pessoas significa potencialmente uma queda de demanda agregada por conta do desaparecimento de consumidores. E quanto mais eles são, mais se expande a capacidade ociosa do sistema econômico, logo aumenta a falta de necessidade de investir.

Terceiro, portanto, o investimento agregado pode se retrair. E nesse movimento, que é recessivo, o quarto impacto é a queda de empregos, da formação e contratação de mais mão de obra, o que pode acelerar o ritmo de desaquecimento econômico.

No momento atual da economia mundial, combalida e afetada pela crise e pela recessão que 
atingiu os Estados Unidos da América, a Europa e os países asiáticos com a exceção mais marcante e notória da China, o advento da gripe suína é conseqüentemente um fator gerador de aprofundamento da crise.

Corresponde a botar mais lenha na fogueira. Só que no lugar de se aumentar a energia positiva que molda os sistemas econômicos e da saúde no mundo, gera-se uma ameaça, que contrai e retrai as pessoas, os agentes econômicos.

No nível microeconômico, é de se esperar que as doenças perigosas e transmissíveis criem efeitos negativos, perversos em numerosos setores econômicos. A vontade de viajar e de fazer turismo em locais infectados tende a cair súbita e abruptamente. Isto contrai o movimento dos transportes aéreos e navais aos centros nos quais as doenças se confirmam como propagadoras; e afeta o setor hoteleiro; de turismo; de alimentação e de acomodações; de lazer e diversões, igualmente. Quanto ao vetor transmissor maior, como suínos, patos, marrecas, galinhas, gambás, cachorros e outros animais que possam ser popularmente identificados temporariamente que seja como ameaçadores, a demanda e o consumo por eles caem, o que evidentemente afeta as indústrias do agribusiness, como a suinocultura, a avicultura e a produção de carnes frigorificadas e embutidos variados.

A lista de contrações na demanda pode ser, deste modo, extensa. E isto significa que às autoridades cabe cuidar da saúde das pessoas preventivamente, pró-ativamente, para que uma doença não ingresse nem afete comunidades. E da mesma forma cuidar da saúde das empresas, para que elas mantenham seus negócios e evitem a perda de demanda, de clientela e a capacidade em gerar bens e serviços que a sociedade local e mundial solicitam.

A mensagem dada elos apelos consistentes da OMS - Organização Mundial da Saúde é, portanto clara: é preciso acentuar medidas de controle pleno e amplo, a favor da sanidade e da obstaculização da transmissão de doenças perigosas.

O Brasil, país emergente e cada vez mais próspero, importante membro dos BRICs e mais recentemente gerador para si mesmo de uma política de estabilidade macroeconômica que o configura como algo menos afeito às contrariedades e dores geradas pela crise deflagrada pelos títulos hipotecários, há de tomar e manter com rigor as políticas de saúde pública que evitarão a introdução dos vetores não desejados no país.

Elas podem doer em curto prazo e gerar desgastes com países e comunidades parceiras. Contudo, mantidas com a devida justificativa e rigor, podem salvar muitas vidas e em certa proporção, a economia.

Entre estas medidas, que cabem às decisões e apreciações das autoridades da saúde e sanitárias do país, centradas no Ministério da Saúde; dos Transportes; da Indústria e do Comércio e da Agricultura, entre outros, figuram o aumento na intensidade da fiscalização e vigilância na importação de bens e serviços; a criação de zonas de quarentena para meios de transportes oriundos de áreas contaminadas; a limpeza e desinfecção completa de meios de transporte e containeres chegados do exterior e de áreas submetidas a pandemias; a proibição temporária da importação de bens oriundos de locais contaminados; o isolamento e a ajuda das pessoas que apresentam indicativos de contaminação, para que se recuperem; e a informação organizada da situação à sociedade civil, instruindo-a sobre os melhores procedimentos e práticas para evitar-se o alastramento das doenças. 


\section{O H1N1 É NÍVEL 6 - SIGNIFICA QUE OCORRE TRANSMISSÃO ENTRE COMUNIDADES}

Ao atingir o nível seis na escala da OMS, a pandemia da Gripe Suína assumiu um lugar de atenção plena e preocupação acentuada em relação à sua capacidade de expansão, alastramento, e os efeitos de morte e mal-estar que é capaz e tem sido capaz de fazer.

Neste sentido, é importante que se evitem e restrinjam as chances de transmissão da doença tal como foi acontecendo. É relevante o aumento de informação e de consciência sobre os impactos gerados pela expansão da influenza no globo terrestre. Para tanto, entre outros, as autoridades dão recomendações de teor e conteúdo variado, que podem ser objetivamente resumidos em medidas internas, afeitas à população local, e medidas externas - fronteiriças e ultramarinas, afeitas às populações de viajantes.

Os dois quadros a seguir, 6 e 7, sumarizam as medidas consideradas mais importantes, e que se verificam tanto no Brasil, quanto na Argentina, o que mostra também a sintonia e a harmonia no trato do assunto de saúde pública, entre ambos os países.

Estas medidas são práticas e bem compreensíveis. Precisariam ser mais divulgadas, pelos meios de comunicação, como orientação e alerta geral, posto que fazem parte de uma forma de se defender as populações dos países e suas comunidades internas.

Quadro 6 - Questões a responder à população, para evitar a Influenza

\section{O que deve fazer a população para evitar a Influenza?}

Tomar todos os cuidados que se fizerem necessários para evitar a doença e contato com ela.

Conhecê-la e entender o que as autoridades recomendam.

Seguir à risca as recomendaçōes das autoridades.

Agir pró-ativamente, utilizando o sugerido e vivendo na busca da normalidade.

Prevenir-se e evitar doenças respiratórias que a ponham exposta.

Lavar as măos com água e sabão, depois de ter tossido ou espirrado; de ter usado o banheiro, de ter comido; de tocar a boca, os olhos e o nariz.

Lavar utensilios, louças, panelas e material de cozinha com sabăo e bactericidas.

Năo repor em panelas e copos colheres usadas e lambidas pelas pessoas.

Usar lenços e papéis descartáveis.

Jogar fora em lixeiras apropriadas todo e qualquer material contaminado por infecçōes, gripes, resfriados, tosses, pigarros, espirros e mucosas fluidas naso-bucais.

Proteger a boca e o nariz com lenços quando tossir ou espirrar.

Evitar sair de casa quando a doença estiver em período de transmissão, isto é, até cinco dias após o início dos sintomas.

Evitar aglomeraçōes e ambientes fechados, mantendo ventilaçăo e ar corrente nos ambientes.

Oferecer luz solar e arejamento aos ambientes caseiros e residenciais, para evitar possíveis agentes de infecçōes.

Criar ambientes limpos (clean), com menos tapetes, e tecidos pesados que empoeiram.

Identificar o agente transmissor. Alertá-lo dos males que traz e indicar o hospital próximo.

Falar com as pessoas que estăo dando sinais de gripe, para que se cuidem e dirijam aos médicos e serviços hospitalares especializados.

Falar e se comunicar com as autoridades da vigilăncia sanitária, para receber e transmitir informaçōes, recomendaçōes e dados.

Evitar a auto-medicaçăo. Falar e tratar-se com profissionais do ramo da saúde.

Fonte: NESPAS / EBAPE / FGV 


\section{VIGILÂNCIA EPIDEMIOLÓGICA}

O papel da Vigilância Epidemiológica é fundamental no processo de identificação, monitoramento e controle de doenças, infecções, novas cepas e de expansão ou não, da doença que se transforma em pandemia.

Isto significa que é relevante especificar e detalhar a Vigilância em suas tipologias entenda-se modalidades. E esperar que ela atue pró-ativamente para estancar, evitar e cooperar no sentido de erradicar as possibilidades de aparição e de disseminação das doenças e infecções. Por estas razões, os papéis atuantes, visíveis, de literais olheiros que se expõem a ver e inspecionar de noite e de dia toda e qualquer pessoa e localidade que possa ser agente que atue na emissão da doença é imprescindível.

A vigilância se faz em várias instâncias e sobre diversos entes e seres vivos. Por isto, esta monitoração pode ser vasta e custosa. Tanto mais, quanto maior é o território de um país, de uma dupla de países ou de um território a ser vigiado por mútuos acordos; maior for o tamanho da população a ser vigiada e controlada; maiores forem em número os acessos para entrada, saída e geração de fluxos e movimentos de bens, serviços, pessoas e seres vivos.

O quadro 8 a seguir sumariza estes aspectos e denominações da vigilância, sobre os quais recai efetivamente a atenção.

Quadro 8 - Tipologia básica e fundamental da Vigilância em Saúde Pública

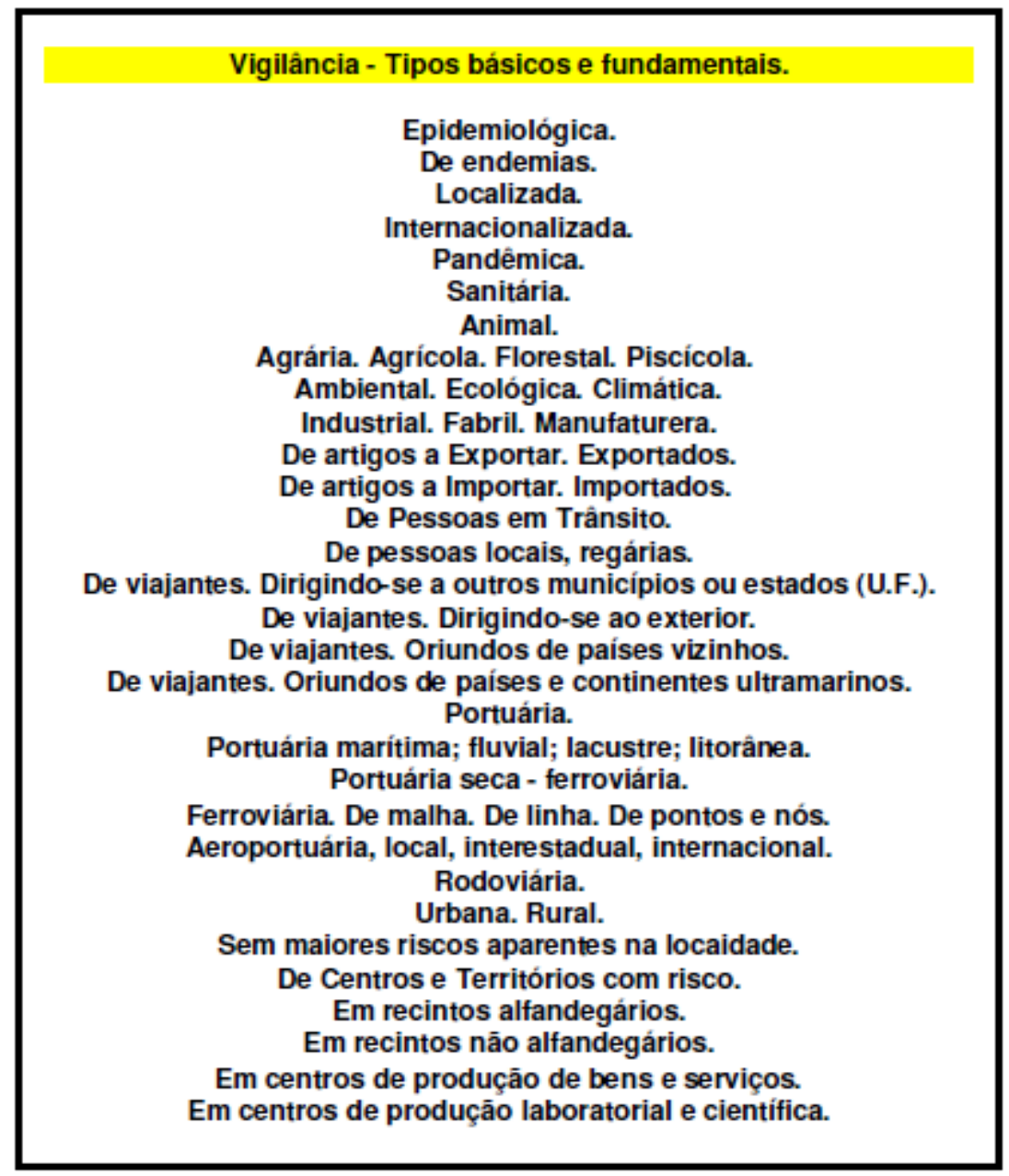

Fonte: NESPAS / EBAPE / FGV 
Outra vertente relevante da Vigilância Epidemiológica diz respeito a definir onde ela surge e aparece, e de que forma se dissemina. Existem naturalmente múltiplas localidades de aparecimento e surgimento de uma nova cepa. 0 objeto desta análise não é de indicar as múltiplas formas de ocorrência, contudo é relevante mostrar emblematicamente uma, para que se possa conforme a necessidade fazer outras identificações. Neste particular, escolheu-se o ato de vigilância a fazer sobre trabalhadores e suas áreas de trabalho.

Isto, porque o trabalhador é precioso e importante como elemento gerador de valor, de riqueza, de renda familiar e de construção da nação. 0 trabalhador pode ser visto como o arrimo de família e o gerador de produtos freqüentemente no piso do chão da fábrica. Logo, qualquer situação que o tire do trabalho, o instabilizará e ameaçará a sua família. Dispor de dados adequados sobre os trabalhadores nacionais, binacionais e internacionais é, portanto, uma forma primordial de preservação da integridade nacional.

E deste ponto de vista dispor de dados e de informações sobre esta classe, para que, bem conhecida e dimensionada, receba o apoio a vigilância compatível coma a necessidade de provimento de sua segurança em saúde, é imprescindível.

O quadro 9 a seguir mostra a importância do apoio de vigilância ao trabalhador, em suas múltiplas e ricas formas e tipologias. Contudo, não é suficiente dar apoio ao trabalhador ativo, até porque, tendo trabalho, recebe renda, logo ao menos de uma forma ou em parte pode pagar por alimentos e saúde, e outras formas de medicação. Isso não ocorre com aqueles que estão desempregados e mal empregados, subempregados ou que são alienados, expulsos do mercado de trabalho. Por não terem nem auferirem renda, além de mais tristes e depressivos, podem não ter capacidade de pagar medicamentos, remédios, para si e seus parentes.

Como conseqüência, esta população de não trabalhadores é potencialmente mais propensa a depressões, perdas de imunidade física e fraquezas, e nem é capaz de pagar seu medicamentos, cestas alimentares e afins. Dispor de sustentação para esta parte da população assisti-la, reempregá-la e acentuar a vigilância sanitária sobre ela, é forma de minimizar seus sofrimentos, além de buscar a recuperação com novos e mais empregos, terapia ocupacional e assistência social, conforme a necessidade.

O quadro 9 a seguir elucida dados e estatísticas a prover, para que os trabalhadores e extrabalhadores, mais potenciais trabalhadores, encontrem na vigilância a sua aliada. 
Quadro 9 - Tipos de dados e informações a levantar e responder, para resguardar a saúde do trabalhador

Saúde do trabalhador: objeto de fundamental Vigilância continua.
Vigilância da saúde do trabalhador.
Levantar o número total de trabalhadores ativos.
Levantar a PEA - populaçao Econômicamente ativa.
Levantar a Populaçao de trabalhadores que possuem registro em Carteira.
Levantar os celetistas.
Levantar aquela parcela do mercado de trabalho que atúa de forma
precária. Maao de obra em condiçoes precarizadas.
Levantar a populaçáo pelos dados do RAIS e faixas de idade e renda.
Levantar a populaçao de profissionais liberais e micro e pequenos empresários.
Levantar a populaçao de empresários. De grandes empresas. De transnacionais.
Levantar a populaçao desempregada.
Levantar a populaçao que procura emprego e nao entende que se "auto-ajustou".
Levantar a populaçao migrante por causa de emprego. Bóias frias.
Verificar flutuaçoes diárias de mao de obra de cidade dormitório a centros.
Verificar flutuaçoes principais da populaçao, independente do trabalho.
Promover atividades de informaçăo, comunicaçao, instruçao aos trabalhadores.
Envolver sindicatos e lideranças sindicais na implementaçao de açoes locais
e regionais que digam respeito aos interesses de segurança e saúde dos
trabalhadores.
Mapear as áreas de risco da saúde dos trabalhadores, inclusive dos riscos
associados a pegar doenças infecciosas transmissiveis por ar, agua e
contatos interpessoais.
Lliberar informaçoes para as empresas e toda a cadeia produtiva.
Verificar as cadeias de produçao com trabalhadores que lidam com animais vivos.
Integrar todas as açoes e medir a sua produtividade.
Repassar as informaçoes em tempo real e solicitar mobilidade na reciprocidade,
no nivel nacional e internacional.

Fonte: NESPAS / EBAPE / FGV

No processo de integração das atividades todo o conjunto de medidas emergenciais de Vigilância sanitária há de ser considerado. A integração é tanto maior, mais forte e coerente, quanto mais assuntos relevantes forem associados, juntados e interconectados.

Isto é mostrado no quadro a seguir, para a ação conjunta da Argentina e do Brasil. 
Quadro 10 - Sugestões de Medidas Emergenciais de Vigilância Sanitária entre Argentina e Brasil

Medidas Emergenciais de Vigilância Sanitária - Argentina - Brasil.

Definiçao das medidas emergenciais nacionais e internacionais com efeitos internos.

Preparaçăo e disseminaçao de processos e métodos de vigilância sanitária.

Definiçao de responsáveis pelo processo de transmissâo e ensino dos métodos.

geraçáo do treinamento e verificaçao in-situ do grau de conhecimento e domínio de técnicas efetivas de vigilância sanitária, pelos colaboradores.

Mapeamento e identificaçao geral e especifica, dos principais corredores efetivos e potenciais de transmissão e contágio de doenças infecto-contagiosas.

Análise de causas e efeitos reais e possiveis, de transmissao e contágio de doenças infecto-contagiosas pelos principais corredores.

Otimizaçao do número de efetivos-colaboradores, por canais e corredores principais.

Otimizaçao tecnológica, de conhecimento, de material e de suporte, aos colaboradores em todos os corredores efetivos e potenciais.

Monitoramento das fronteiras e canais nacionais. Formaçao de estatísticas relevantes e análise em tempo real de ocorrências e decisoes sanitárias, de saúde e profiláticas.

Emissao e Transmissão de informaçoes brasileiras sobre quadro situacional interno e por canais e corredores do país.

Emissăo e Transmissao de informaçoes brasileiras, diretamente afeitas à relaçao Argentina-Brasil, em: aeroportos; portos; vias fluviais, rodoviárias e ferroviárias, e cidades fronteiriças.

Recebimento e Interpretaçao de informaçoes argentinas, sobre o quadro situacional interno e por canais e corredores do pais.

Recebimento e Interpretaçao de informaçoes argentinas, diretamente afeitas à relaçao Argentina-Brasil, em: aeroportos; portos; vias fluviais, rodoviárias e ferroe por canais e corredores do país.

Reuniao e Integraça Bilateral dos Agentes e representantes da Vigilância Sanitária Argentino-Brasileira, com a finalidade de traçarem e manterem politicas públicas de Saúde e de Vigilância conjuntas, favoráveis aos interesses dos dois paises e da comunidade da América do Sul.

Reuniao Bilateral dos Agentes e representantes da Vigilância Sanitária ArgentinoBrasileira, para avaliaçăo de resultados e repasse de informaçoes entre si; a favor da comunidade da América do Sul e para a OMS.

Fonte: NESPAS / EBAPE / FGV

Em parte significativa, o sucesso da erradicação da pandemia da Gripe Suína será função da agilidade e da velocidade, associada a precisão, com a qual as autoridades de todos os países conseguirem em conjunto adotar meditas imediatas em aeroportos, portos, rodoviárias, rodovias, estações e alfândegas de fronteira.

Equipes de vigilantes, inspetores, fiscais e analistas médicos que perceberem com rapidez quem é portador de uma doença, ou cria ameaças à comunidade pelos sinais que emite, inclusive sem saber, terão e possuem especial relevância.

0 ato de se derrubar uma epidemia ou uma endemia depende muito de quem "está na ponta", ou dito de outra forma, na "linha de tiro", isto é, na área de relacionamento operacional e de movimentação maior das populações viajantes, emigrantes e viajantes.

Caso, com saber, tirocínio, experiência, tato e rápido espírito perceptivo, os vigilantes treinados e as autoridades comunicativas implementarem de imediato as ações que se 
fizerem necessárias, as chances de combate às infecções aumentarão significativamente.

Isto enaltece o quão importante é ter assertividade, experiência, pró-atividade e logo velocidade nas ações antipandemia.

0 quadro 11 a seguir busca fortalecer e resumir esta vertente analítica da necessária ação imediata.

Quadro 11 - Ações Imediatas a Tomar (continuar adotando) em Aeroportos, Portos, Rodoviárias, Estações e Alfândegas Fronteiriças, entre a Argentina e o Brasil

Açöes Imediatas a Tomar em Aeroportos, Portos, Rodoviárias, Estạ̧ōes e Alfandegas Fronteirị̧as Argentina - Brasil.

Recebimento e Inspeçäo integral de todos os passageiros; transportadores e turistas, com abertura e detalhamento do quadro médico sanitário individual pessoal e origem,

Realizaçăo de pente fino sobre meios de transporte provenientes de locais onde a infecçäo é e permanece ativa.

Realizaçāo de fiscalizaçōes intensiv as nas principais rotas e canais de acesso de imigrantes oriundos de paises nos quais a infecçăo permanece ativa.

Cercamento efetivo de aeronaves, viaturas e naves, cuja rota e presença em zona fronteiriça admita riscos de presença de pessoas que visam imigraçäo ou entrada ilegal nos paises.

Tratamento amigo e integral, educativo, a todos quantos chegam e circulam.

Geraçäo de cartazes, anúncios e circulares que ampliam as informaçōes e ajudam a criar consciência coletiva sobre as vantagens de saber tratar-se e ajudar solidáriamente o próximo.

Atençăo especial para alienigenas provenientes de zonas infectadas.

Aatençăo especial para alienígenas e nativos provenientes de locais onde a infecçäo é ativa.

Recebimento prévio e antecedente, com 5 dias prévios ao menos, de informaçōes sobre cargas vivas.

Inspeção de animais e seres vivos em detalhe, especialmente mamiferos.

Suspensäo e interdiçăo de entrada de cargas viv as ao menor sinal de doença, risco e existência de dúvidas sobre sanidade.

Colocaçäo em isolamento, quarentena e tratamento qualificado, o agente confesso portador de doença infecto-contagiosa, o que apresente sinais suspeitos associados a infecçōes. Aviso a familiares e facilitaçäo da vida dos internados.

Aviso às autoridades internacionais, OMS e ao país de origem do infectado.

Definiçăo de politicas de tratamento por individuo, para acompanhamento no pais de tratamento e no pais de origem.

Fonte: NESPAS / EBAPE / FGV

Com a finalidade de exemplificar uma atividade anterior, que possui similitudes em seu trato na Argentina e no Brasil, com pequenas diferenças, freqüentemente sutis, todavia com os fundamentos bem alicerçados e iguais na prática, vale mostrar como se pensa e age contra a pandemia na área portuária. E como base de referência, será utilizada a entidade nos dois países que versa sobre o assunto. Na Argentina, significativa parte das orientações advem da Dirección de Regulación, Fiscalización y Sanidad de Fronteras; assim como das áreas e dos órgãos que lidam com e atendem por nomes de Puertos, Aeropuertos, Ferrocarriles, e Carreteras, entre outros. No Brasil, agências como Secretaria Especial de Portos, ANAC e o Ministério dos Transportes possuem ações semelhantes.

No plano da Saúde, recomendações importantes e adicionais para portos, aeroportos e fronteiras são disponibilizados na ANVISA e mediante seu site.

A preocupação com a pandemia de gripe suína A - H1N1 emergiu com a propagação mundial do vírus influenza aviária H5N1, que demonstrara ser de grande letalidade, geradora da gripe aviária, mal que gerou $61 \%$ de mortes nos casos registrados no mundo inteiro.

No caso da SEP - Secretaria Especial de Portos, criou-se por meio da Portaria do dia 29 de abril de 2009 um conjunto de Unidades de gestão Ambiental Portuária. Desenvolveram-se 
ademais o sistema de controle pandemico e as salas de situação para se verem implantadas nos portos. Neste processo, estão previstos implantações dos programas vinculados à Fauna Sinantrópica Nociva e à saúde do trabalhador que atua em portos.

As ações da SEP, em conjunto com a ANVISA, procuram ofertar ás autoridades dos portos as ferramentas que são necessárias para a adoção de ações eficazes e que sejam preventivas, em concomitância e harmonia com as demais autoridades portuárias. É objetivo a permanente vigilância para alterações necessárias ao atendimento das novas características do vírus recém aparecido.

Como efeito, as medidas e ações a fazer são as seguintes:

- Aumentar a intensidade de vigilância de casos suspeitos em vôos provenientes das áreas afetadas, com conhecimento e abordagem mais próximo dos viajantes procedentes e oriundos das áreas afetadas. afetadas.

- Solicitar a Declaração de Bagagem Acompanhada (DBA), parte relativa à informação dos viajantes, de todos aqueles viajantes que são oriundos de locais afetados com a influenza.

- Aplicar e utilizar o fluxo de informação constante no plano que diz respeito a Portos e Aeroportos.

- Emitir o TCSV, conhecido como Termo de Controle Sanitário de Viajantes, perante e diante a identificação de viajantes que são chegados das áreas afetadas e que apresentam sintomas clínicos que sugerem ou comprovam um quadro infeccioso, o que convida à geração imediata de cópias e seu envio aos órgãos de defesa da saúde pública, através de emails como notifica@saude.gov.br e notifica.ggpaf@anvisa.gov.br.

- Utilizar os equipamentos de proteção individual - EPI, nas investigações e averiguações de casos que apresentarem evidências de sintomas clínicos que dão evidências ou sugerem um quadro infeccioso.

\section{PREPARAÇÃO PARA ENFRENTAR A PANDEMIA DA INFLUENZA}

Equipes nacionais e multinacionais de combate a pandemias chegam às áreas afetadas ou que estão em regime de suspeita com sua bagagem e conhecimento de origem, associado a conhecimentos, treinamentos e experiências adquiridas no país ao qual representam. Naturalmente, ao agregarem as indicações oriundas da Organização Mundial de Saúde - OMS, da qual ambos são signatários, trazem consigo conhecimentos valiosos que permitem tratamentos imediatos com satisfatório para elevado grau de conhecimento.

No quadro 12 a seguir, é apresentada em síntese a forma de se lidar com os grupos de vigilantes que irão a campo, aos locais nos quais sabe-se existir a influenza ou suspeitase que ela é capaz de eclodir. 
Quadro 12 - Mapa de preparo de enfrentamento da Pandemia da Influenza

Preparação para enfrentar a Pandemia da Influenza.

Monitorar no campo aberto, na zona rural e nas granjas os animais em geral, com foco atual em suinos.

Monitorar, acompanhar, registrar e fiscalizar a movimentaçao nas estaradas e vias de transportes, das cargas vivas de suinos e de carnes e embutidos por industrializar e industrializadas.

Verificar as áreas e os micropontos de localizaçăo e concentraçao de gripes e doenças.

Realizar nas áreas de maior concentraçáo habitacional e de doenças, Seminários de Sensibilizaçáo e cursos técnicos práticos, prontos ao ensino e à entrega de material de trabalho útil para o exercicio imediato de funçoes.

Convidar e envolver rápidamente, com avisos pré-agendados, os técnicos municipais e provinciais das vigilâncias epidemiológicas, de assistência, da rede hospitalar, de laboratórios, de rede de voluntários e das redes de saúde, para aumento e domínio do conhecimento e capacitaçao plena de açào em momentos que se asseveram como de ocorrência de influenza e que clamam por açoes práticas imediatas.

Ter monitores, inspetores, vigilantes aptos a detectar pessoas com chances de infectaçao, tratadas com educaçao, paciência e alta civilidade, ao emitirem tosse; sinais de dor nas articulaçoes; dor de garganta, cabeça prostraçao, dificuladade de respirar e que tenham viajado ou estado em contato com gente que tenha ido a lugares afetados e infectados.

Observar e revisitar pessoas cujo quadro clínico tenha inspirado dúvidas, especialmente no $3^{\circ}$ até $07^{\circ}$ dias após aparente ou real exposiçăo.

Ser ágil na obtençăo e na análise de amostras para fins laboratoriais. Dispor de todos pos kits que sejam necessários para fazer os exames clínicos, médicos, analitico laboratoriais para reconhecer o virus a - $\mathrm{H} 1 \mathrm{~N} 1$ e suas recentes mutaçoes.

Onde se fizer mais necessário, dispor de meios sofisticados de transporte, como avioes helicópteros e ambulâncias modernas, com mini-laboratórios e sistema de comunicaçoes integrado a todo o pais e ao pais vizinho por satélite.

Nao se ater a uma vacina sazonal para influenza, posto que ela pode ter pouca ou nenhuma proteçao para a influenza A - $\mathrm{H}_{1} \mathrm{~N} 1$.

Dispor nos dois países uma açao haronica, que siga as recomendaçoes da OMS e estejam em consonância com as medidas adotadas e de boas práticas adotadas em ambos os paises.

Fonte: NESPAS / EBAPE / FGV

É preciso ficar atento às conseqüências diretas e indiretas de uma pandemia. As causas diretas foram analisadas e debatidas em especial no item que diz respeito aos impactos econômicos da pandemia.

Contudo, existem situações e efeitos não negligenciáveis de teor indireto, que afetam a comunidade e antes de ocorrerem, precisam ser previstas, listadas, analisadas em suas causas e efeitos e monitoradas com soluções aderentes às suas reais dimensões, freqüentemente custosas.

No quadro 13 que segue, apresentam-se diversas conseqüências indiretas da Pandemia. Algumas surgem como situações "oportunistas", tais como o aumento da criminalidade e saques a residências e estabelecimentos. A rigor, numa indesejável situação extrema, o alto índice de mortalidade provocado por uma pandemia cuja cura não se encontra ou seria excessivamente demorada, geraria a ruptura da tessitura organizacional e hierarquizada das organizações sociais públicas e privadas. Sem sentirem a aposição e imposição da força e da justiça, por perda de substância no processo de gestão pública, no caso da segurança pública, gangues e ladrões de toda sorte poderiam surgir, invadindo residências, estabelecimentos comerciais públicos e privados, para se apossarem de bens e serviços. Isto exigiria superior e supremo esforço das forças públicas, para que, mesmo tendo perdas de pessoal em suas 
próprias hostes, fossem capazes de fazer face às demandas públicas e punissem exemplarmente a criminalidade.

Problema e desafio similar é enfrentado pelas comunidades nacionais quando significativos desastres e acidentes da natureza chegam de súbito e abalam o seu equilíbrio, tais como os adventos de grandes inundações; terremotos; incêndios; tsunamis e afins. Num primeiro momento, de espanto, surpresa e estupor, podem acontecer uma desorganização social e das organizações que produzem a segurança pública. Desta paralisia se aproveitam os fora da lei, para criarem um "rent-seeking" rápido e súbito para si, sem respeito à dignidade, ao patrimônio e ao sofrimento alheio.

Por estas razões, a administração em regime de continências de pandemias e epidemias de teor de gravidade e alcance maior transcende a ação exclusiva das políticas públicas da saúde, da medicina e da vigilância sanitária. É importante contar e estabelecer relações claras e definidas com os provedores de segurança pública; de justiça formal e institucional; de transportes; de comunicações; de alimentação, habitação e abrigos, entre outros. Esta rede múltipla acomodará melhor a demanda por serviços públicos e o combate aos problemas de saúde terá melhor fim, a favor da população afligida.

Quadro 13 - Tentativa de antever possibilidades de ocorrências de eventos indesejáveis no futuro - situações passíveis de ocorrer

Situaçōes passiveis de ocorrer, e consequências indiretas da Pandemia aguda.

Alta taxa de mortalidade em creches, orfanatos, escolas e repúblicas de estudantes. Alta taxa de mortalidade em cortiços, áreas pobres e de baixa renda, como palafitas. Alta taxa de moratalidade em favelas e zonas de habitaçao precária.

Alta taxa de mortalidade em cárceres, delegacias de polícia com celas lotadas e presidios carcerários.

Alta taxa de mortalidade em hoteis e pensionatos da terceira idade.

Significativa taxa de mortalidade em condominios verticais elevados e fechados.

Significativa taxa de mortalidade em ruas tradicionais, estreitas, antigas, pouco arejadas.

Crescente e significativo indice de absenteismo de alunos em escolas; universidaddes.

Crescente e significativo índice de absenteismo de trabalhadores nas empresas.

Crescente e significativo indice de absenteismo em Igrejas, Teatros, Eventos, afins.

Incapacidade de puniçao por absenteismo nas empresas reduz oferta geral de bens e serviços. Surgem demandas reprimidas; preços ascendentes; mercados paralelos; especulaçoes com produtos; dificuldades de importaçao; menores estoques regudores; filas; cotas; cupons; sistemas de atendimento por cupons; privilegiados; administraçăo em regime de carência, arbitrio e exceçăo.

Os clientes e as pessoas em geral se fecham, se resguardam, se comunicam menos. Todavia, em contrapartida, precisam de mais comunicaçao pública e informaçao para romper e coibir temores e tomarem as decisoes alocativas e de interrelaçao social que sejam acertadas.

Potencial colapso e estrangulamento na oferta agregada de bens e serviços Ocorre uma queda generalizada na produçăo e na dinâmica do comércio em todos os setores.

Casas, andares, prédios, condomínios, ficam mais vazios, mais desativados. Grupos de assaltantes, gangsteres e outros assumem controle de localidades, em caso de ausência da forças policiais e da legalidade. A sinalizaçăo contínua da manutença da força, da legalidade e da aplicaçao da Lei na Justiça, é fundamental.

Aumenta o transporte de doentes e de mortes. A morte é visivel por rua e local.

Aumenta o número de zonas de isolamento e de quarentena.

Aumenta a criaçao de valas comuns e pontos de concentraçao de cadáveres.

Aumenta o comércio da indústria da morte e dos enterros.

Aumenta a oferta de medicamentos, máscaras descartáveis, kits de combate à influenza e espera-se que seja ela maior que a necessidade, nao apenas a demanda agregada. O uso maciço da informaça pública de saúde e da medicaçăo pode ajudar a vergar a pandemia e suas terriveis consequências.

Pessoas, oportunistas e gatunos surjem como herdeiros dos mortos, pessoas e familias inteiras que morrem ou adoecem gravemente perdem suas fortunas e posses.

A indústria da advocacia de heranças e sucessoes floresce e se enriquece.

Em sendo grave e crescente a Pandemia, sua penetraça longa e virulenta gera uma grande crise social. A populaçao mais pobre é relativamente mais afetada, contudo a pandemia pode arrasar talentos e pessoas valiosas em todas as camadas sociais.

Fonte: NESPAS / EBAPE / FGV 


\section{CONCLUSÃo}

A Argentina e o Brasil vêm trilhando e construindo ao longo de décadas um sólido e firme trabalho de consolidação de suas políticas públicas de saúde. Como resultado, os dados da OMS vêm evidenciando que os indicadores de saúde nos dois países estão apresentando sinais inequívocos de melhoria de curto, médio e longo prazo. Ambos os países se afinam e afirmam diálogos participativos construtivos, na área de saúde e um bom caso, exemplar, é o que sucede no campo da gestão de políticas públicas integradas de influenza.

Os desafios são enormes, dignos de países emergentes e modernos, que são líderes e compartilham do interesse social e trabalhista com finalidades desenvolvimentistas próprias, em regime de salutar mutualidade.

Este estudo mostra que as similitudes estruturais da saúde nos dois países resultaram em medidas que beneficiaram a cada um internamente e ao mesmo tempo reverberaram em efeitos positivos em clima de boa vizinhança. Por estas razões, em que pesem obviamente súbitos problemas, cuja gravidade pega de surpresa ou ao menos sem data marcada as comunidades, pode-se manter e ampliar o grau de relacionamento entre as autoridades que com afinco e abertura que consolida os movimentos progressistas nacionais, sucede entre ambos os países. Isto repercute no MERCOSUL, na América do Sul e na América Latina. E mostra que o trabalho em equipe, estruturado e claro, sobrepõe-se aos mais delicados e complexos problemas e desafios, como o da Gripe Suína, beneficiando no final, de fato, a todos os cidadãos.

\section{BIBLIOGRAFIA}

A H1N1 - Argentina, 4 muertes y 733 contagiados; 16/06/2009. América do Sul está preparada para a Gripe, diz OMS; noticias.ambientebrasil.com.br/noticia; 2009.

Caso Sospechoso de Gripe Porcina em la Argentina; Argensur; 27/4/2009.

CDC H1N1 Flu Update: U. S. Human Cases of H1N1 Flu Infection; H1N1 Flu Centers for Disease Control and Prevention; 05/06/2009. Costa, Dani;

Identificada mutação da Gripe Suína no Brasil; e Doença faz mais três vítimas na Argentina; Diário de São Paulo e O GLOBO; pg. 24 O Mundo; 17 de junho de 2009.

Diretrizes Gerais para o trabalho em Contenção com material Biológico; Ministério da Saúde; Secretaria de Ciência e Tecnologia e Insumo estratégico; 2004.

El Gobierno Confirmo el segundo Caso de Gripe Porcina en la Argentina; Crítica de La Argentina.; 22/05/2009.

Golan, Ralph, M. D.; Optimal Wellness; Ballantine Books; New York; 1995.

Gripe A: Hay 15 nuevos casos e investigan una muerte en Jujuy; Clarin; 31/05/2009.

Gripe Porcina: Admiten que la Situación es Seria pero que no hay casos en Argentina; Clarín; $27 / 4 / 2009$.

Health Protection Agency: Swine Influenza - UK Government. Gripe:; Reino Unido pasa a Eespaña en Número de Casos; Estadão, SP; 28/05/2009.

Influenza 09: Spanish - language reources for the Latino Community; OMS: 4.694 casos de 
Influenza A H1N1 en el mundo; influenza09.wordpresss.com; 2009.

H1N1 Flu Virus - 2009; The Kansas Department of Health and Environment; www.kdheks.gov/H1N1. Johnson, Timothy; On Call Guide to men's Health; Hyperion; New York; 2002. Kasznar, Istvan;

A Realidade da Saúde no Brasil: o Cálculo do Produto Interno Bruto (PIB) do Setor entre 1994 e 1999; NESPAS - Núcleo de Estudos da Saúde, da Previdência e da

Assistência Social; da EBAPE - Escola Brasileira de Administração Pública e de Empresas, da FGV - Fundação Getúlio Vargas; apoio IBRE - Instituto Brasileiro de Economia; 1999.

Kasznar, Istvan e Bayma, Fátima; Saúde e Previdência Social; Volume 1; Desafios para a Gestão do próximo Milênio; Makron Books; FGV - Fundação Getúlio Vargas; 2001.

Kasznar, Istvan e Bayma, Fátima; Saúde e Previdência Social; Volume 2; Desafios para a Gestão do próximo Milênio; Prentice Hall; FGV - Fundação Getúlio Vargas; 2003.

Kasznar, Istvan e Bayma, Fátima; Saúde, Previdência e Assistência Social; Volume 3; Desafios e Propostas para uma Sociedade mais Justa e Moderna; M.Books; FGV - Fundação Getúlio Vargas; 2005.

Kasznar, Istvan e Bayma, Fátima; Saúde e Previdência Social; Volume 4; Políticas Públicas Integradas. Desafios e Propostas Estratégicas; Pearson - Prentice Hall; FGV - Fundação Getúlio Vargas; 2007.

Kiple, Kenneth F.; Plague, Pox and Pestilence - Disease in History; Barnes \& Noble Books; New York; 1997.

Más colégios cerrados por el avance de la Gripe Porcina; La Nación; 3/05/2009.

Meltzer, Ml.; Cox, N. J.; Fukuda, K.; The economic impact of pandemic influenza in the United States: priorities for intervention; Emerging Information dis.; 5 (5), 659-671; 1999.

Lyons, Albert S. E Petrucelli, Joseph; Medicine; Abradale Press; Harry N. Abrams, Inc. Publishers; 1987.

OMS declara pandemia de Gripe Suína; Wikinotícias; Agência Brasil; 12 de junho de 2009.

Organização Mundial da Saúde; Wikipedia; pt.wikipedia.org/wiki/Organiza; 2009.

Pandemia; Subsecretaria de Planejamento e Desenvolvimento Portuário; Secretaria Especial de Portos; Presidência da República; Departamento de Revitalização e Modernização Portuária; www.portosdobrasil.gov.br/procedimentos -contingenciais; 18/06/2009.

Pandemia de Gripe de 2009 na América do Sul; Wikipedia; www.wikipedia.org/wiki/Pandemia_de_gripe_de_2009; 2009. Pandemia de Gripe de 2009 na América do Norte; Wikipedia; www.wikipedia.org/wiki/Pandemia_de_gripe_de_2009; 2009.

Penna, T. C. V.; Métodos de desinfecção e esterilização; em Mastroeni, M. F. - Organizador; Biossegurança Aplicada a Laboratórios e serviços de Saúde; São Paulo; Atheneu; 2004.

Perez D. R.; Sorrell, E. M.; Doris, R. O.; Avian Influenza: an omnipresent pandemic threat; P.I.D.; 
november 24; 11 Supplement; s 208-216; S 215; 2005.

Plano Brasileiro de Preparação para uma Pandemia de Influenza - 3@ versão; Ministério da Saúde; Brasília, abril de 2006.

Plano Brasileiro de Preparação para uma pandemia de Influenza; da Silva Jr., Jarbas Barbosa; Secretario de Vigilância em saúde; Ministério da saúde; Rio de Janeiro, Novembro de 2005.

Plano de Preparação para Pandemia de Influenza do Estado de São Paulo - Diretrizes Gerais; Suplemento BEPA; São Paulo 2005.

Plano Estadual de Contingência para Enfrentamento de uma pandemia de Influenza Proposta de Pernambuco; Vigilância Sanitária; Secretaria de saúde; Governo de Pernambuco.

Plano de Preparação para Enfrentamento da Pandemia da Influenza no Estado da Bahia;

Lorene Pinto; SUVISA - SESAB; Governo da Bahia; Secretaria de Saúde; 13 de Maio de 2009.

Plano de Preparação para o Enfrentamento da Pandemia de influenza; Secretaria de Estado da Saúde; SUS - Sistema Único de Saúde; Estado de Santa Catarina; 2006.

Planning and Response Activities; PandemicFlu.gov; www.avianflu.gov Processo de Implantação da Vigilância Epidemiológica da Influenza em mato grosso - Pandemia de Influenza; 16/06/2009.

Reporte semanal de la Situación de Influenza A.; redsalud.govcl ; Colombia; 28/05/2009.

Situación Actual de la Epidemia de Influenza A (H1N1); Associated Press; 06/05/2009.

Who; World Health statistics; anos 2005 a 2008; http : //www.3.who.int/statistics/ ; 2009.

World Health Organization; Plan Mundial de la O. M. S. De Preparación para una Pandemia de Influenza; WHO; Genebra; 2005.

www.anvisa.gov.br

www.agricultura.gov.br

www.agroportal.sp.gov.br

www.butantan.gov.br

www.who.int/influenza

www.oie.int

www.fao.org

www.cdc.gov/flu/avian/index

www.hhs.gov/nvpo/pandemicplan/annex2.pdf

www.saude.gov.org 